\title{
The sympathies of the body: functional organization and neuronal differentiation in the peripheral sympathetic nervous system
}

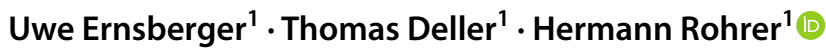

Received: 4 August 2021 / Accepted: 20 October 2021 / Published online: 10 November 2021

(c) The Author(s) 2021

\begin{abstract}
During the last 30 years, our understanding of the development and diversification of postganglionic sympathetic neurons has dramatically increased. In parallel, the list of target structures has been critically extended from the cardiovascular system and selected glandular structures to metabolically relevant tissues such as white and brown adipose tissue, lymphoid tissues, bone, and bone marrow. A critical question now emerges for the integration of the diverse sympathetic neuron classes into neural circuits specific for these different target tissues to achieve the homeostatic regulation of the physiological ends affected.
\end{abstract}

Keywords Noradrenergic $\cdot$ Cholinergic $\cdot$ Heartrate $\cdot$ Hypertension $\cdot$ Hydromineral $\cdot$ Thermogenesis $\cdot$ Adiposity $\cdot$ Immune status $\cdot$ Bone marrow $\cdot$ Skeletal health $\cdot$ Transdifferentiation $\cdot$ Synaptic organizer

$\begin{array}{ll}\text { Abbreviations } \\ \text { ALTE } & \text { Apparent life-threatening event } \\ \text { ANS } & \text { Autonomic nervous system } \\ \text { BAT } & \text { Brown adipose tissue } \\ \text { ASCL1 } & \text { Achaete-scute family bHLH transcription } \\ & \text { factor 1 } \\ \text { BAX } & \text { BCL2 associated X, apoptosis regulator } \\ \text { BDNF } & \text { Brain-derived neurotrophic factor } \\ \text { BMP } & \text { Bone morphogenetic protein } \\ \text { CCHS } & \text { Congenital central hypoventilation syndrome } \\ \text { CHAT } & \text { Choline acetyltransferase } \\ \text { CKD } & \text { Chronic kidney disease } \\ \text { CNS } & \text { Central nervous system } \\ \text { DBH } & \text { Dopamine beta hydroxylase } \\ \text { GATA } & \text { GATA binding protein } \\ \text { GFR } & \text { Glial cell line-derived neurotrophic factor } \\ & \text { receptor } \\ \text { GP 130 } & \text { Interleukin } 6 \text { signal transducer } \\ \text { HAND } & \text { Heart and neural crest derivatives expressed } \\ \text { HRV } & \text { Heartrate variability } \\ \text { L1CAM } & \text { L1 cell adhesion molecule } \\ \text { NCAM } & \text { Neural cell adhesion molecule }\end{array}$

Uwe Ernsberger

ernsberger@outlook.de

$\triangle$ Hermann Rohrer

rohrer@med.uni-frankfurt.de

1 Institute for Clinical Neuroanatomy, Goethe University, Frankfurt/Main, Germany

$\begin{array}{ll}\text { NGF } & \text { Nerve growth factor } \\ \text { PCDH } & \text { Protocadherin } \\ \text { PHOX2B } & \text { Paired-like homeobox transcription factor } 2 b \\ \text { RET } & \text { Ret proto-oncogene } \\ \text { RSNA } & \text { Renal sympathetic nerve activity } \\ \text { SCG } & \text { Superior cervical ganglion } \\ \text { SHH } & \text { Sonic hedgehog } \\ \text { SIDS } & \text { Sudden infant death syndrome } \\ \text { SNS } & \text { Sympathetic nervous system } \\ \text { TH } & \text { Tyrosine hydroxylase } \\ \text { TF } & \text { Transcription factor } \\ \text { TRK } & \text { Neurotrophic tyrosine kinase receptor } \\ \text { VACHT } & \text { Vesicular acetylcholine transporter } \\ \text { WAT } & \text { White adipose tissue }\end{array}$

\section{Introduction}

According to the Danish anatomist Winslow, the great sympathetic or intercostal nerve is the principal means of bringing about the sympathies of the body (Winslow 1732; Langley 1921). In the almost 300 years since then, the progress of discoveries in the field of the autonomic nervous system, including the sympathetic nervous system, spins at an ever increasing rate. The progressing understanding of the cellular properties realized in the autonomic sympathetic and parasympathetic system (Ernsberger and Rohrer 2018), and in particular, in the postganglionic sympathetic neurons (Ernsberger et al. 2020), now becomes refined to 
molecular detail by single cell RNA sequencing (Furlan et al. 2016; Blum et al. 2021). Together with the studies on the integration of these neurons in autonomic reflex pathways, a comprehension of the circuits maintaining bodily homeostasis is developing (Jänig 2006). Their importance in the balancing regulation of a large number of physiological parameters as much as in the causation of a grand spectrum of autonomic disorders (Goldstein 2017, 2019) explains the ever-growing interest in autonomic neuroscience and autonomic medicine.

Here, we review key data on the importance of the sympathetic nervous system in homeostatic regulation of a range of crucial processes ranging from heartbeat and organ perfusion to water and mineral balancing, regulation of body temperature and metabolic expenditure, and the balancing of the immune system and skeletal health. We discuss the importance of target-selective sympathetic pathways to selectively regulate the different tissues involved in these processes. And we consider the developmental mechanisms for the generation of this cellular system and its integration into target-directed neural circuits.

\section{Key regulatory domains served by the sympathetic nervous system}

From the "sympathies of the body" (Winslow 1732), the "constant milieu interieur" (Bernard 1957) the "wisdom of the body" (Cannon 1932), and the "neurobiology of homeostasis" (Jänig 2006) to the "principles of autonomic medicine" (Goldstein 2017), a comprehensive view is growing on the anatomy, physiology, pharmacology, genetics, and clinic of the autonomic nervous system. In particular, the sympathetic branch has been characterized in great detail, and its balancing interaction with the parasympathetic system is key consideration in medical physiology.

For a long time, the sympathetic/parasympathetic antagonism on heart activity and the sympathetic control of the vascular system constituted the prime focus of this analysis. With the increased interest in metab olic control and glucose homeostasis, the growing problem of adiposity and its linkage to cardiovascular and renal disorders, as well as the tight link with immune homeostasis and the interaction between nervous and immune system, this focus has been considerably extended. A detailed knowledge of the sympathetic efferent innervation of a wide range of target tissues from blood vessels, endocrine, and adipose tissue to lymphoid tissue and bone marrow widens our view of sympathetically regulated systems. An ever-increasing body of experimental and clinical studies reveals how deeply the sympathetic nervous system (SNS) intervenes in the most diverse aspects of bodily functions (Fig. 1; Table 1).

\section{Sympathetic/parasympathetic balancing in the control of heart beat and its derailment in heart failure}

During the late nineteenth century, the opposing action of the vagal and sympathetic nerve supply on heart activity (von Bezold 1863; Bayliss and Starling 1892) became experimentally accessible. The observation of "antagonistic cardiac nerves" and their effect on heart rate in dogs (Samaan 1935) were complemented by studies in cats and condensed into a mathematical model of the "interrelations of vagal and accelerator effects on the cardiac rate" (Rosenblueth and Simeone 1934). Characterization of baroreceptor and chemoreceptor activation reflexes allowed to integrate the model of this antagonistic system into a homeostatic, sensory inputdriven model emphasizing the antagonistic control of organ function by the sympathetic and parasympathetic system put forward by Cannon as well as nonantagonistic central control patterns as emphasized by the Brooks laboratory (Kollai and Koizumi 1979; Koizumi and Kollai 1992).

In parallel, heartrate variability (HRV) emerged as a promising tool for studying autonomic control and its central regulation (Task Force of the European Society of Cardiology and the North American Society for pacing and Electrophysiology 1996). HRV analysis is now acclaimed for its growing role as remote digital biomarker for neurovisceral integration and health in everyday life (Owens 2020) as much as for its extension to neonatal intensive care as a measure for discomfort and complications (Chiera et al. 2020).

Despite the advanced understanding of heartrate control by balancing activities of the sympathetic and parasympathetic domains of the autonomic nervous system, heart failure, different from other cardiac disorders, showed rising prevalence (Braunwald 2013; Savarese and Lund 2017). One key feature of heart failure, augmented sympathetic outflow to the heart, kidney, and muscle with chronically elevated sympathetoexcitatory reflexes (Floras 2009; Esler and Kaye 1998), demonstrates how a valuable balancing system serving homeostatic processes can be derailed to initiate a vicious circle of disease progression (Borovac et al. 2020; Zhang and Anderson 2014). Causes for this destructive readjustment can be abnormal cardiovascular reflexes associated with cardiac or renal dysfunction and central processes with chronic SNS overactivity as one of the key pathophysiological mechanisms. Thus, dysregulation of sympathetic/parasympathetic balance results in adverse alterations not only on cardiac, but also on renal or immune functions (Floras and Ponikowski 2015). 


\begin{tabular}{|c|c|c|c|c|c|c|c|}
\hline $\begin{array}{l}\text { Heart } \\
\text { rate }\end{array}$ & $\begin{array}{l}\text { Blood } \\
\text { pressure }\end{array}$ & $\begin{array}{l}\text { Water } \\
\text { mineral }\end{array}$ & $\begin{array}{l}\text { Thermo } \\
\text { regulation }\end{array}$ & $\begin{array}{l}\text { Energy } \\
\text { balance }\end{array}$ & $\begin{array}{l}\text { Immune } \\
\text { status }\end{array}$ & $\begin{array}{l}\text { Bone re - } \\
\text { modeling }\end{array}$ & $\begin{array}{l}\text { Sympathetic } \\
\text { target }\end{array}$ \\
\hline & & & & & & & Heart muscle \\
\hline & & & & & & & Coronary aa \\
\hline & & & & & & & Skin aa \\
\hline & & & & & & & Muscle aa \\
\hline & & & & & & & Splanchic aa \\
\hline & & & & & & & Renal aa \\
\hline & & & & & & & Sweat glands \\
\hline & & & & & & & Skin hairs \\
\hline & & & & & & & BAT \\
\hline & & & & & & & WAT \\
\hline & & & & & & & Pancr. islet \\
\hline & & & & & & & Liver \\
\hline & & & & & & & Spleen \\
\hline & & & & & & & Lymph node \\
\hline & & & & & & & Tertiary LT \\
\hline & & & & & & & Thymus \\
\hline & & & & & & & Bone MSCN \\
\hline & & & & & & & Bone OST \\
\hline & & & & & & & \\
\hline
\end{tabular}

Fig. 1 Regulatory domains in homeostatic demands, employed neurotransmitter systems and target tissues innervated by sympathetic postganglionic efferents. The figure displays the sympathetic transmitter systems employed in different target tissues. blue, noradrenergic; red, cholinergic. The data have been obtained by immunehistological detection of tyrosine hydroxylase as key marker for noradrenergic sympathetic neurons and by pharmacological discrimination of noradrenergic versus cholinergic activator or inhibitor-mediated actions. In the case of rodent sweat glands, also immunohistochemistry for choline acetyltransferase and the vesicular acetylcholine transporter have been employed in combination with retrograde labeling. Abbreviations: aa, arteries and arterioles; BAT, brown adipose tissue; MSCN: marrow stem cell niche; OST: osteoblast/osteoclast; Pancr., Pancreatic; LT: lymphatic tissue; WAT: white adipose tissue 
Table 1 Domains of sympathetic homeostatic action, critical diseases and sympathetic target tissues

\begin{tabular}{lll}
\hline Domain & Diseases & Sympathetic target tissues \\
\hline Cardiovascular & Heart failure, hypo- and hypertension & $\begin{array}{l}\text { Heart and large arteries } \\
\text { Intermediate-sized arteries }\end{array}$ \\
& & Arterioles \\
& & Large venous reflux vessels \\
Water and mineral balance & Chronic kidney disease & Kidney blood vessels \\
Thermoregulation & & Glomeruli and tubules \\
& Hypo - and hyperthermia & Skin, muscle, and internal \\
& & blood vessels \\
Glucose and energy balance & Hypoglycemia and adiposity & Sweat glands \\
& & Brown adipose tissue \\
Immune homeostasis & & Pancreatic islets \\
& Immune-mediated inflammation & White adipose tissue \\
Skeletal health & & Hepatic blood vessels \\
& & Bone marrow and thymus \\
& & Spleen and lymph nodes \\
& & Tertiary lymphatic tissues
\end{tabular}

\section{Blood pressure control}

The continuous requirement for integrated balancing action on the cardiovascular system by the autonomic nervous system during everyday life is nicely illustrated by the adjustments required within the first minute of standing up (Harms et al. 2021). The concerted action of the sympathetic and parasympathetic nervous system on heart performance and vasculature control that may be requested at intervals of less than minutes demand a balancing system of high reliability. CNS degenerative disorders frequently present with neurogenic orthostatic hypotension where these short-term autonomic control processes are insufficient (Idiaquez 2021).

The sympathetic efferents, most important for the control of mean blood pressure, constitute barosensitive units whose basal activity is directed by a network of brainstem and hypothalamic neurons (Guyenet 2006). In addition to the sensitivity of the efferent units to baroreceptor activity, the regulation of their activity state by sodium, oxygen, hormones, cytokines, osmolality, and $\mathrm{pH}$ nicely delineates a number of key parameters central to homeostatic control. Interestingly, this regulation also entails a respiratory modulation of sympathetic nerve activity aimed to increase the efficiency of oxygen uptake, perfusion, and cardiac performance (Molkov et al. 2014; Häbler et al. 1994).

Basic control of the blood pressure by the ANS occurs on a beat-to-beat basis typically on a timescale of seconds as required in orthostasis (Hart and Charkoudian 2014). Longterm changes in blood pressure control are typically required in changing performance, altered endurance, or with disease conditions during time. The comparison between young men and women, postmenopausal women, and old men unravels relevant differences in control mechanisms due to gender and age (Hart and Charkoudian 2014). The setpoint and key sensors of long-term blood pressure control remain an ongoing research challenge (Osborn et al. 2005; Brands 2012).

With the development of a mathematical model for blood pressure control, Guyton and colleagues provided a way to combine an analysis of the multifactorial system at a quantitative level (Guyton et al. 1972). The central importance of the renal function curve and balancing of salt and water depending on blood pressure is critical to the renal body fluid-pressure control system (Guyton 1990). Continuing exploration of this model and the obligatory role of the kidney in long-term blood pressure control and the linkage between blood pressure and sodium balance remained of vivid interest (Dorrington and Pandit 2009; Montani and Van Vliet 2009). The role of the nervous system turned into an issue of increasing importance (Osborn et al. 2009) and requested to improve classic modeling by a neurogenic model (Averina et al. 2015). In addition, gender-specific differences in long-term blood pressure control became subject of experimental and modeling analysis (Ahmed et al. 2019). Between men and women as well as within women, availability of and sensitivity to ovarian hormone exposition affect blood pressure and water regulation (Wenner and Stachenfeld 2012).

The enormous interest to understand qualitative and quantitative aspects of blood pressure control rests in the necessity to manage blood pressure in a variety of disabling and disease processes. In an incept cohort study among citizens in Framingham, Massachusetts, it was shown that high blood pressure is the most common risk factor for heart failure (Levy et al. 1996). Long-term trends in incidence and survival demonstrate gender specific differences (Levy et al. 2002). In the discussion of therapeutic strategies to prevent heart failure, intensive blood pressure lowering is a first option (Jafari et al. 2020). The major impact of the 
development of beta blockers to blunt noradrenergic sympathetic neurotransmission (Quirke 2006; Walker 2011) to fight hypertension (Kelly 1976; Carcel et al. 2019) points at the importance of the SNS in this regulatory system. The effect of combination therapies with beta blockers and inhibitors of the renin-angiotensin system for the treatment of heart failure highlights the importance of the SNS and the kidney (Nochioka et al. 2018; Martin et al. 2018).

\section{The kidney - site of water and mineral balance and effector of the sympathorenal axis in chronic disease}

Renal sympathetic efferents exert a key role in water and mineral balance (Osborn et al. 2021). The regulation of renal function via glomerular filtration, sodium reabsorption, and renin release is crucial for adaptation processes at different time scales. By balancing the intake of water and electrolytes via ingestion, metabolic production of water, and excretion, an essential hydromineral homeostatic process is coordinated by aligning neural and endocrine processes in the kidney (Mecawi et al. 2015). A large degree of flexibility in the system allows individuals to operate safely despite large inter-individual differences in water uptake (Armstrong and Johnson 2018). Different from humans and other monogastric mammals, in ruminants, in addition to the kidney, the salivary glands, gastrointestinal tract, and liver essentially contribute to fluid and electrolyte homeostasis and allow existence under severe dehydration followed by rapid rehydration episodes (Silanikove 1994). Selection and breeding of domestic ruminants led to local breeds selected for their ability to dwell and withstand the challenges posed by largely diverse climatic conditions including prolonged periods of water deprivation.

The effects of renal sympathetic nerve activity (RSNA) on renal blood flow and glomerular filtration rate, tubular sodium, and water reabsorption, as well as renin release in humans, are analyzed in great detail (DiBona et al. 1997; Johns et al. 2011; Johns 2013). Increasing and decreasing RSNA show opposite effects with pathological sympathetic excitation causing sodium retention as well as blood pressure elevation (Armstrong and Johnson 2018). Its association with a series of serious comorbidities such as hypertension, heart disease, and diabetes (Belayev and Palevsky 2014; Sata et al. 2018) demonstrate how deeply the renal sympathetic efferents impact autonomic homeostasis. Blockade of sympathetic noradrenergic neurotransmission or renal denervation has shown suitable to block progression from acute kidney injury to chronic kidney disease (CKD) and to battle resistant hypertension (Noh et al. 2020; Quarti-Trevano et al. 2021).

In an extension of the model by Guyton and colleagues (see above), mechanisms of RSNA on sodium reabsorption and renin secretion were integrated (Karaaslan et al. 2005). In this manner, a model of long-term cardiovascular regulation was provided that accounts for the effect of RSNA on kidney function. This allows to simulate the consequences for RSNA and sodium excretion depending on sodium intake (Karaaslan et al. 2014).

The renocardiovascular link provided by the sympathetic efferents and the renin-angiotensin system turns out operational in essential hypertension, heart failure, CDK, and obesity/metabolic syndrome (Blankestijn et al. 2011). The identification of the renal nerve as a key therapeutic target now allows modulatory therapy, currently by nerve ablation (Schlaich et al. 2012). The observation of the increased RSNA activity associated with hypertension and of the curative effect of nerve ablation sparked an intensive debate on the question whether increased SNS activity is the dominant, sufficient, and necessary cause or may be a consequence of a diverse array of hypertensive disorders (Esler et al. 2010; Navar 2010). In a long series of comments, it appeared that the jury was hung up on the verdict (Bie and Damkjaer 2010). This discussion on the role of renal medullary perfusion continues until today (Booth et al. 2015; Bie and Evans 2017; Bądzyńska et al. 2021).

Currently the characterization of the sympathetic postganglionic system involved in the "circulatory, filtration, re-absorptive, excretory, and renin secretory contributions to overall renal function" (DiBona 2000) is incomplete. Analysis with RNA sequencing, as described below for other sympathetic neuron populations, of this diverse and functionally highly relevant sympathetic neuron population can be expected to further the comprehension of the diversity in this renal efferent innervation to judge physiological and pathophysiological roles of individual efferent neuron classes.

Taken together, the sympathorenal axis features prominently in a range of chronic diseases such as essential hypertension, heart failure, functional renal diseases, diuretic resistance, and insulin resistance accompanied by excessive central and peripheral sympathetic drive (Sobotka et al. 2011). How this relation can be quantitatively and mechanistically understood is one of the key questions in ANS function, dysfunction, and medicine.

\section{Temperature control: a lifesaving balancing process extending to the edge of performance and endurance limits}

Maintaining a relatively elevated and stable body temperature is critical for human survival, ensuring suitable conditions for the metabolic processes and consequently for tissue and organ integrity (Tansey and Johnson 2015). This balancing endeavor is so essential that thermoregulation is frequently cited as the prototypic example of a 
homeostatic process achieved to a large part by autonomic nervous control of a selective set of anatomical structures (Johnson et al. 2014). Heat and cold challenges can elicit a range of physiological responses regulated by distinct sympathetic efferent pathways, including vasodilation and vasoconstriction for blood redistribution and heat convection between skin and internal organs, sweating for heat dissipation by evaporation, nonshivering thermogenesis to burn fats uncoupled from metabolic energy transfer, and piloerection important for insulation in hairy skin of many mammals.

Human thermoregulation relies largely on sympathetic sudomotor and vasomotor target pathways (Francisco and Minson 2018). Changes in skin blood flow can increase or decrease convective heat transfer from internal tissues to the periphery, thereby increasing or decreasing heat loss to the environment (Francisco and Minson 2018; Kellogg 2006; Charkoudian 2010). Sympathetic noradrenergic nerves, tonically active in a normothermic environment, mediate vasoconstriction in many vascular beds, whereas vasodilator nerves, without resting tone, mediate profound active vasodilation in glabrus skin. The understanding of the molecular processes in active cutaneous vasodilation is still incomplete but attributed to a cholinergic transmission with multiple cotransmitters (Francisco and Minson 2018). The characterization of the premotor pathways driving vasoconstriction and sweating is well underway, while the central pathways in active vasodilation are unknown (McAllen and McKinley 2018).

In humans, the thermoregulatory response with the greatest capacity for heat loss during physical activity and environmental heat exposure is sweating. It serves the bulk part of heat dissipation, and whole body sweat rate is closely linked to the evaporation requirement for heat balance (Gagnon et al. 2013). A review of comparative responses in men and women to heat stress discloses gender and age-specific differences (Kenney et al. 2014; Kenney 1985). Older people exhibit altered responses during heat stress with delayed onset of sweating and a reduction in sweat rate (Balmain et al. 2018). Whether this reduction in sweat rate is due to changes in the sweat gland or in the cholinergic sympathetic sudomotor transmission remains unclear.

In older people, there is also an impairment of heatinduced rise in skin blood flow (Balmain et al. 2018). This blunted rise in vasodilation, attributed to a compromised cholinergic sympathetic active vasodilator system, together with the reduced sweating capacity in older people, indicates that with age two sympathetic cholinergic target systems for thermoregulation become impaired. In addition to the impaired cutaneous vasodilation and sweating response, the increase in cardiac output of older individuals, a noradrenergic sympathetic target system, seems blunted as well (Kenney et al. 2014; Gravel et al. 2021).
Despite the basic thermoregulatory capacities, exercise, especially in a hot environment, can cause significant increases in internal body temperature (Kenny and McGinn 2017). Age, gender, acclimation, fitness, and chronic disease have profound consequences on the body's ability to offset this temperature increase, and impairment may lead to sustained increases in core body temperature. Extreme conditions such as heat waves may exceed the limits of compensability in vulnerable people (Kenny and McGinn 2017; Balmain et al. 2018).

The ability to improve the regulatory competences by physical exercise and balanced heat exposure programs, in addition to dietary supplements, proves the plasticity of the autonomic homeostatic systems within personal limits. Endurance competition programs such as Iron Man triathlons in different climate zones and ultra-demanding, longdistance running competitions in the Sahara or Arctic climate zones show to which limits these regulatory systems can be stretched (Tansey and Johnson 2015; Balmain et al. 2018).

Running and swimming competitions in Arctic climate and icy water point towards another sympathetic target branch for thermoregulation. Brown fat innervation by sympathetic noradrenergic neurons is a critical effector for heat generation in brown adipose tissue by nonshivering thermogenesis (Cannon and Nedergaard 2004). In fact, brown (BAT) and white adipose tissue (WAT) are innervated by the SNS and show a wide presence of nerve terminals (Contreras et al. 2017; Blaszkiewicz et al. 2019). While postsynaptic beta 3 receptors activate lipolysis in WAT, thermogenesis is activated in BAT, such that both adipose tissues contribute to the regulation of energy balance.

Acclimation, gender, and age-specific prevalence of brown fat depots in humans indicate plasticity within the sympathetically mediated brown adipose tissue thermogenesis (Richard et al. 2012). Attenuation of the response of brown adipocytes to cold in aged humans (Graja and Schulz 2015) together with the markedly impaired reflex cutaneous vasoconstriction in response to cold stimuli in healthy older persons (Greaney et al. 2015) show that two sympathetically controlled systems to counter cold stressors are impaired with age. Taken together, sympathetic regulation during thermal stress is compromised along several sympathetic target pathways during human aging and disease and critically affects the ability to withstand both heat and cold stressors (Greaney et al. 2015).

In a comprehensive compilation of the efferent, afferent, and central neurons involved in the regulation of body temperature, a wiring diagram is developed that shows the participating sympathetic postganglionic neurons (Madden and Morrison 2019). With the neurotransmitters employed, the scheme provides part of the neurochemical code driving the regulatory system (as shown in Fig. 2 of Madden 


\begin{tabular}{|c|c|c|c|c|c|c|c|c|c|}
\hline $\begin{array}{l}\text { neuron } \\
\text { class }\end{array}$ & $\begin{array}{l}\text { TrkA/ } \\
\text { NTRK1 }\end{array}$ & RET & GFRa2 & GFRa3 & PCDH7 & PCDH9 & PCDH10 & PCDH17 & $\begin{array}{l}\text { PCDH } \\
\text { A5 }\end{array}$ \\
\hline NA 1 & & & & & & & & & \\
\hline NA 2 & & & & & & & & & \\
\hline NA 3 & & & & & & & & & \\
\hline NA 4 & & & & & & & & & \\
\hline NA 5 & & & & & & & & & \\
\hline $\mathrm{ACH} 1$ & & & & & & & & & \\
\hline $\mathrm{ACH} 2$ & & & & & & & & & \\
\hline & & & & & & & & & \\
\hline
\end{tabular}

Fig. 2 Expression of growth factor receptors and synaptic organizers of the protocadherin gene family in mouse thoracic sympathetic neuron classes. Expression level for the genes encoding the indicated receptor and organizer genes at larger than 0 (grey), 2 (yellow), 4 (orange), 8 (red), or 16 (dark red) mRNA molecules per cell. Data are taken from Furlan et al. (2016). While all noradrenergic neuron subpopulations (NA 1-5) show strong TRKA expression, the cholinergic sympathetic neurons show abundant RET expression. However, RET transcripts are detected in all, also noradrenergic sympathetic neuron classes. This observation was also made by quantitative density analysis of NBT/BCIP signals obtained from in situ hybridization in mouse cervical and thoracic sympathetic ganglia (UE, unpublished). Transcripts for GFRa receptor subunits can be detected at relatively low levels. GFRa1 and GFRa4 transcripts are not or barely observed (not displayed). GFRa3 is detected at very low levels in NA 1-5 but

and Morrison 2019). The molecules responsible for wiring this network are to a large extent unknown. With the characterization of mouse thoracic sympathetic neurons by RNA sequencing (Furlan et al. 2016), the expression of transcripts for synaptic organizer molecules in sympathetic piloerector neurons is available (Ernsberger et al. 2020) that may be part of a neuron class-specific wiring code.

For sympathetic neurons innervating the other efferent branches relevant for temperature regulation and metabolic homeostasis, the organizer molecules are not yet known. Since these sympathetic neuron classes are involved in the critical balancing process between food availability and temperature control (Nakamura and Nakamura 2018), further characterization of the sympathetic efferent classes not in ACH 1 and ACH 2. Only GFRa2 is observed in significant levels in the cholinergic neuron populations and at low levels in noradrenergic neurons. For protocadherin transcripts, several important aspects could be derived from the single cell RNA sequencing data published by Furlan et al. (2016). Compared to other cell adhesion and synaptic organizer molecules, the PCDH gene family members are expressed very selectively in the different classes of sympathetic neurons (Ernsberger et al. 2020). For PCDH17, significant transcript levels are detected only in cholinergic neurons, not in noradrenergic neurons. The expression levels for PCDH 7, 9, 10, and A5 make it possible to distinguish all sympathetic neuron classes observed in the study. The transcripts of selected genes of the family could be detected at similar levels compared to those for TRKA and GDNFfamily ligand receptors

and their synaptic organizer molecules will be of distinct interest.

\section{Glucose and metabolic homeostasis: engaging different sympathetically innervated tissues}

Similar to the densely innervated brown adipose tissue involved in nonshivering thermogenesis, white adipose tissue is richly innervated by sympathetic fibers to regulate lipolysis and fat mobilization (Bartness et al. 2014). Innervation density in WAT is not as high as in BAT and detection required improved histological techniques for tissue clearing, yet roughly $90 \%$ of white adipocytes were observed to have nerve terminals nearby. In addition to adipocytes, 
pancreatic islets and liver are innervated by sympathetic fibers indicating a role for sympathetic efferent regulation in glucose homeostasis and lipid mobilization via different effectors (Lin et al. 2021).

Dense sympathetic and parasympathetic innervation of pancreatic islets is indicative of autonomic regulation of hormone production important for glucose homeostasis, with sympathetic activation decreasing insulin release and increasing glucagon release (Porte and Williams 1966; Ahrén et al. 1987; Lin et al. 2021). In hypoglycemic situations, this may induce a counter-regulating glucagon response (Taborsky et al. 2002). Sympathetic innervation in the liver is also involved in maintenance of glucose homeostasis by affecting net glucose uptake (Moore et al. 2012) and activating glycogenolysis (Shimazu 1996).

WAT also exerts an endocrine function and dynamically communicates with other tissues through secretion of adipokines, most importantly leptin (Lin et al. 2020). Circulating leptin inhibits food intake, depletes fat mass, and enhances glucose metabolism. Since leptin-sensitive central neuronal circuits converge onto efferent sympathetic neurons, the regulation of WAT activity by sympathetic efferents is organized in a leptin-sympathetic-leptin feedback loop (Mark et al. 2003; Kalil and Haynes 2012).

The derailment of these systems is a hallmark at the fringe of obesity and hypertension, major drivers of cardiovascular and kidney diseases (Bell and Rahmouni 2016; Hall et al. 2019). A key link between obesity and cardiovascular disease is leptin, and hyperleptinemia or leptin resistance in human obesity influence cardiovascular structure and function, inflammatory processes, and sympathetic activity that is stimulated in obese patients (Kang et al. 2020) with obvious gender differences (Shi et al. 2020). The neuroendocrine loop facilitated by adipose tissue-derived leptin and SNSderived noradrenaline additionally engages in crosstalk with resident immune cells (Larabee et al. 2020).

\section{Sympathetic innervation of lymphoid tissues: harnessing the self/nonself discrimination for host defense and bodily maintenance}

The perception of the autonomic nervous system as a mediator in homeostasis became considerably expanded starting in the 1960s. Immunohistochemical detection of tyrosine hydroxylase, the rate limiting enzyme for catecholamine biosynthesis, and the cell type-specific feature of noradrenergic postganglionic sympathetic neurons provided evidence for autonomic innervation in primary and secondary lymphoid tissues, notably the thymus (Felten and Felten 1989), bone marrow (Bjurholm et al. 1988), and the spleen (Fillenz 1970; Bellinger et al. 1987). Consequently, the autonomic innervation of lymphoid tissues turned into a key topic, demonstrating that all primary and secondary lymphoid tissues receive substantial sympathetic innervation (Felten and Felten 1991; Stevens-Felten and Bellinger 1997; Nance and Sanders 2007).

The presence of adrenergic receptor molecules on diverse immune cell types and the presence of sympathetic nerve fiber varicosities in primary and secondary lymphatic tissues strongly indicate classical neurotransmission (Bellinger et al. 2008). Intense sympathetic innervation is also detected in tertiary lymphoid tissue located at the meninges (Rua and McGavern 2018). Taken together, the sympathetic nervous system is now recognized as the integrative interface between two super systems, the brain, and the immune system (Elenkov et al. 2000; Wrona 2006).

Regulation of host defense by the SNS and immune homeostasis via adrenergic receptors on immune cells affects development, survival, proliferation, circulation, trafficking, and recruitment of the respective cell types (Bellinger and Lorton 2014). Consequently, this regulation impacts the activational state and functional capacity of immune cells, suggesting a critical link to the development and exacerbation of chronic immune-mediated diseases. Overall, the interaction of the nervous and the immune system are critically involved in mediating "tissue and whole body homeostasis" (Rankin and Artis 2018).

Hypertension and associated comorbidities (Lori et al. 2017) and nonpathogen-driven chronic immune-mediated diseases (Bellinger and Lorton 2018) represent examples where the homeostatic balance breaks down. In both cases, a maladaptive disease-inducing or perpetuating sympathetic response is observed and may be promoted by regional inflammation and immune dysfunction. A critical hub appears to be the spleen, where both systems are tightly linked throughout adult life. Elevated sympathetic tone, immune cell infiltration in the affected organs, and an impaired pressure/natriuresis relationship play crucial roles in hypertension and chronic kidney disease-associated homeostatic derailment (Rodriguez-Iturbe et al. 2017; Zhang et al. 2021). In neurodegenerative disease settings such as synucleinopathies or diabetic neuropathy, where also inflammatory and vascular mechanisms may converge, key autonomic disturbance may be orthostatic hypotension or neurogenic bladder and bowel dysfunction (Sasaki et al. 2020; Idiaquez et al. 2021).

\section{Sympathetic innervation of bone and bone marrow: regulation of skeletal health and lymphoid cell generation}

Sympathetic efferent innervation to bone has major effects on bone development, remodeling, and aging on the one hand, as well as lymphoid stem cell formation and hematopoietic stem cell and progenitor cell trafficking on the other (Katayama et al. 2006; Elefteriou 2018; Fielding and 
Méndez-Ferrer 2020; Tomlinson et al. 2020). Thus, sympathetic innervation to the bone and bone marrow contributes to skeletal health and immune homeostasis.

Both the noradrenergic and the cholinergic neurotransmitter systems are employed by the sympathetic postganglionic system to the bone. With diurnal rhythmic activities of sympathetic noradrenergic as well as cholinergic efferents, migration of hematopoietic stem cells and leukocytes from bone marrow are regulated (del Toro and Méndez-Ferrer 2013; García-García et al. 2019). In addition, together with complex hormonal changes during pregnancy and lactation, sympathetic efferent outflow orchestrates bone remodeling across longer timescales (Winter et al. 2020). Finally, alterations of sympathetic system activity with aging as observed by HRV analysis in elderly (Nicolini et al. 2012) and the agerelated decline to frailty and late-life vulnerability (Walston 2015) disclose plasticity on long biological timescales (Otto et al. 2020). In disease, autonomic nervous dysfunction may link disruptions in bone remodeling and immune status as observed in osteoporosis in multiple sclerosis (Sternberg 2018).

With the demonstration of leptin as a powerful inhibitor of bone formation (Ducy et al. 2000) and evidence from DBH-deficient mice and pharmacological intervention that the leptin action on bone formation occurs via the sympathetic nervous system (Takeda et al. 2002), the noradrenergic sympathetic pathway regulating bone homeostasis became a key topic. A critical finding was the demonstration that among the two phases of bone remodeling, bone resorption, and bone formation, the former is favored by sympathetic nervous activity due to promoting an osteoclast differentiation pathway through noradrenergic transmission (Elefteriou et al. 2005). A sympathetic dominance during aging may come with disturbed bone remodeling observed in osteoporosis (Elefteriou 2018).

With the demonstration of cholinergic differentiation in initially noradrenergic sympathetic neurons innervating bone (Asmus et al. 2000), requirement for GFRalpha-2 for cholinergic sympathetic fiber innervation at the periosteum (Hiltunen and Airaksinen 2004), the differences in noradrenergic and cholinergic pathways to different bone envelopes (Bataille et al. 2012), and the involvement of cholinergic sympathetic activity in the regulation of hematopoietic stem cell and leukocyte migration (García-García et al. 2019), the generation and function of these cholinergic sympathetic neurons becomes a new focus of interest.

Thus, the diverse sympathetic innervation to bone and bone marrow and consequently its involvement in the regulation of skeletal health on the one hand and hematopoietic stem cell dynamics on the other prompt the questions for the generation of the neuronal diversity involved and for the wiring of the diverse sympathetic neuron types to their target cells as well as their preganglionic input.
The domain specific access to sympathetic targets: the concept of target-specific sympathetic pathways

Sympathetic efferent activity shows parallel responses to many stimuli but differences may occur according to targets, such as the heart and kidney, and the stimulation setting (Guyenet 2006; Jänig and McLachlan 1992). Differential activity patterns are best shown by recordings from selected nerve filaments supplying different targets (Esler 2010). In the period from 1970 to 2010, a large amount of observations on differential regulation of the sympathetic activity destined towards distinct target tissues was compiled, and different or even opposite changes in the sympathetic outflow to different domains of the cardiovascular system in response to thermal stimuli represent a critical observation (Jänig and Häbler 2000; Iriki and Simon 2012).

Consequently, the efferent action of the sympathetic nervous system to its highly diverse target organs and the need to appropriately balance a variety of body functions and parameters require a specified signaling. The assumption that indices of SNS drive to the heart, skeletal muscle, or skin can be generalized in the line of thinking of Cannon's "fight and flight response" with a uniformly activated SNS can be misleading (Bartness et al. 2014).

This change in the perception of the patterning of sympathetic outflow is nicely captured in a summary by Morrison: “... the early views of the sympathetic nervous system as a monolithic effector activated globally in situations requiring a rapid and aggressive response to life-threatening danger have been eclipsed by an organizational model featuring an extensive array of functionally specific output channels that can be simultaneously activated or inhibited in combinations ..." (Morrison 2001). New data sets on single cell transcriptomes have the potential to unravel the organizing molecules which may be involved in the generation of these specific output channels.

\section{Domains of progress in understanding the generation, specification, and connectivity of sympathetic neuron classes}

With their landmark study on the growth stimulatory effects of mouse sarcoma on the sensory and sympathetic nervous system in chick embryos (Levi-Montalcini and Hamburger 1951), Levi-Montalcini and Hamburger laid out a key concept in molecular developmental neuroscience (Levi-Montalcini 1987). The working of nerve growth factor (NGF) on sympathetic neurons fits perfectly into the frame of the neurotrophic theory (Oppenheim 1989) stating that a set of neurons in a population will die because trophic factors are available only in limiting amounts, in case of 
NGF corresponding to the size of the innervated target field. Thus, early developmental neuroscience was dominated by a concept of size adjustment between neuron populations and corresponding target field.

Another important move forward was the characterization of a set of growth factors involved in differentiation and patterning and their induction of neuronal and noradrenergic differentiation in neural crest-derived progenitors to develop into sympathetic neurons (Rohrer 2011). With the induction by these growth factors of a transcription factor network with cross-regulatory properties dominated by the PHOX $2 b$ master regulator (Pattyn et al. 1999), the development of the sympathetic autonomic cell lineage became understandable in molecular terms. At the same time, failures in proliferative control by this network make this system prone to tumorigenesis and explain derailment of sympathetic neuron differentiation to childhood tumor formation.

This progress is now accelerated by a major technical advancement, single cell RNA sequencing. The identification and characterization of sympathetic preganglionic and postganglionic neurons by their full transcriptome allows specific molecularly guided characterization of the diverse autonomic nerve cell classes. Developmental analysis is performed by the combination of RNA sequencing and the analysis of genetically labeled neuron classes (Furlan et al. 2016). Moreover, information contained in these single cell transcriptomes on gene products involved in electrical activity (ion channels and transmitter receptors) or synapse formation and synaptic information propagation (synaptic proteins, synaptic organizers, and cell adhesion molecules) promise the study of generation and function of targetspecific efferent pathways.

\section{Neural crest precursor migration and initial sympathetic differentiation: generation of mixed noradrenergic/cholinergic neuroblasts by a PHOX2b-directed transcription network prone to malignancy}

The progenitor cells destined to form neurons in the sympathetic ganglia are derived from the neural crest, a transient structure at the dorsal tips of the closing neural fold (Kalcheim 2018). The cells undergo an epithelial-to-mesenchymal transition to then follow ventrally directed migration routes towards the sites of initial differentiation in primary sympathetic ganglia adjacent to the aorta (Bronner-Fraser 1995; Kulesa et al. 2009). Upon arrival in the vicinity of the dorsal aorta, differentiation events result in the coordinated expression of noradrenergic as well as neuronal properties (Rohrer 2011; Ernsberger 2000).

Growth factors critically involved in this inductive process are bone morphogenetic proteins 4 and 7 that become expressed in the wall of the developing aorta (Reissmann et al. 1996; Shah et al. 1996; Schneider et al. 1999). In addition, a notochord-derived signal was found important in early experiments in the chick embryo (Groves et al. 1995). Importantly, BMPs and notochord-derived sonic hedgehog have shown to be instrumental in the differentiation of sympathetic neurons from human pluripotent stem cells (Huang et al. 2016; Oh et al. 2016; Frith and Tsakiridis 2019).

The growth factor-induced differentiation process is driven by a transcription factor (TF) network critically involving PHOX2b, HAND1 and HAND2, and GATA2 and GATA3, linked by cross regulatory capacity (Rohrer 2011; Ernsberger and Rohrer 2018; Ernsberger et al. 2020). Notably, PHOX2b is required for initiation of the noradrenergic and neuronal differentiation process (Pattyn et al. 1999) and for maintenance of noradrenergic marker expression in differentiated neurons (Coppola et al. 2010). A comprehensive outline of expression and function of these transcription factors in sympathetic neuron development and their importance in the regulation of progenitor and neuroblast proliferation and differentiation is provided by studies from several laboratories in different mammalian and avian species (Ernsberger and Rohrer 2018).

Importantly, in noradrenergic neuroblastoma cell lines, super enhancers that govern gene expression programs are associated with gene loci for the TFs PhOX2a and $2 b$, HAND2, and GATA2 and 3 (Boeva et al. 2017; van Groningen et al. 2017). Deregulation of embryonic neural crest (NC) development results in this NC-derived pediatric malignancy (Tomolonis et al. 2017; Johnsen et al. 2019). Already more than a decade ago, the importance of PHOX2b and DeltaNotch pathway has been observed in a number of familial neuroblastoma (van Limpt et al. 2005; Raabe et al. 2008). Analysis of the action of neuroblastoma PHOX $2 b$ variants in developing sympathetic neurons demonstrated their stimulatory effect on neuroblast proliferation combined with dedifferentiation indicating routes to malignancy modulated by PHOX2b in combination with HAND2 (Reiff et al. 2010). Studies for other transcription factors of the network directing sympathetic neuron differentiation and their role in neuroblastoma exist for GATA3 (Almutairi 2019; Moriguchi 2021) and ASCL1 (Wang et al. 2019; Ali et al. 2020).

Apart from their involvement in the formation of pediatric solid tumors (Capasso et al. 2020; Pudela et al. 2020), PHOX2B mutations leading to polyalanin-expansion cause congenital central hypoventilation syndrome (CCHS) (Keywan et al. 2021). In addition to CCHS PHOX2B variants define a broad phenotypic spectrum, including Hirschsprung disease, apparent life-threatening event (ALTE) and sudden infant death syndrome (SIDS) (Bachetti and Ceccherini 2020). These observations demonstrate the key strategic role of PHOX2b-guided 
developmental processes in critical life-sustaining functions.

Segregation of noradrenergic neuronal and adrenergic endocrine sympatho-adrenal lineages occurs early during development, with endocrine cells in the adrenal medulla generated from Schwann cell precursors as determined in mouse and human embryogenesis (Furlan et al. 2017; Jansky et al. 2021; Kameneva et al. 2021). Minor differentiation capacity from Schwann cell precursors to sympathetic neuroblasts can be detected in human sympathoadrenal development as observed by single cell RNA sequencing (Kastriti et al. 2019; Kameneva et al. 2021).

During initial differentiation in the sympathetic neuron lineage, cholinergic properties are detectable soon after noradrenergic induction in birds and mammals (Ernsberger et al. 1997; Huber and Ernsberger 2006; Furlan et al. 2013; Huang et al. 2013). These neurons are considered to be of mixed neurotransmitter phenotype. Subsequently, a segregation process starts which rapidly leads to the restriction of the noradrenergic or cholinergic transmitter synthesis and vesicular storage capacities in distinct sympathetic postganglionic neurons innervating specific target tissues.

Taken together, neural crest-derived progenitors migrating through somatic mesenchyme towards the aorta are induced to engage in an orchestrated differentiation process by BMPs and SHH, growth factors involved in dorsal-ventral embryonic patterning. Among the first markers indicative of this differentiation process are a set of TFs dominated by PHOX2b, GATA3, and HAND1 and 2 followed by the noradrenergic neurotransmitter phenotypic enzymes and transporters. Surprisingly, cholinergic properties are detectable only with short delay, producing early neurons of mixed transmitter phenotype. A peculiarity in sympathetic neuron development is the maintenance of proliferative activity after initial differentiation (Rothman et al. 1978; Rohrer and Thoenen 1987). For the differentiation process proper, precursors or neuroblasts exit the cell cycle to then reenter proliferative activity (Gonsalvez et al. 2013). The generation of the pediatric tumor neuroblastoma from sympathoadrenal progenitors and the importance of TFs of the sympathetic neuron differentiation pathway in tumor generation point towards a soft spot in the system.

\section{The generation of sympathetic neuron diversity: a complicated process composed of embryonic target-independent and postnatal target- dependent events}

The generation of the mature neuron classes from the early, often mixed noradrenergic and cholinergic neuroblasts is a process that rapidly commences embryonically after initial differentiation and extends well into the postnatal period (Cane and Anderson 2009; Ernsberger et al.
2020). Control of this process by growth factors and transcriptional regulators became a focus of research (Rohrer 2011) since the trans-differentiation of sympathetic neurons innervating rodent sweat glands during early postnatal maturation was described (Francis and Landis 1999). Consequently, the target-dependent determination of the neurotransmitter phenotype in sympathetic ganglia became a key topic in developmental neurobiology (Schotzinger et al. 1994), while target-independent differentiation processes remained neglected for some time.

PHOX2b, critical for the initial differentiation process, is required for induction of both the noradrenergic (Pattyn et al. 1999) as well as the cholinergic properties (Huber and Ernsberger 2006) as demonstrated in mouse embryos. RET signaling is essential for the maintenance of cholinergic marker expression, choline acetyltransferase (CHAT), as well has the vesicular acetylcholine transporter (VACHT), throughout embryogenesis but not for its initial induction (Burau et al. 2004; Furlan et al. 2013). Mutational inactivation in mice leads to the loss of cholinergic marker expression, without apparent effect on the expression of noradrenergic properties such as $\mathrm{TH}$ and $\mathrm{DBH}$. However, target tissues innervated by these embryonically cholinergic sympathetic neurons and their postnatal fate are not known. Many cholinergic sympathetic neurons are only generated postnatally by trans-differentiation from noradrenergic neurons.

The embryonic segregation of functional marker gene expression from mixed noradrenergic/cholinergic neuroblasts to mature neurons with either noradrenergic or cholinergic neurotransmitter phenotype was studied in detail in chick and mouse embryos. Experimental analysis in rodents documented the restriction of the enzymes and the vesicular neurotransmitter transporters for the noradrenergic and cholinergic neuron phenotypes at mid-embryonic stages before innervation of the final targets (Ernsberger et al. 1997; Huber and Ernsberger 2006; Furlan et al. 2013). This developmental transition coincided with the appearance of TRK A and the disappearance of RET and TRK C expression in the majority of sympathetic neurons (Fagan et al. 1996; Furlan et al. 2013). The homeobox transcription factor 1 (HMX1) is required for the TRK A expression as well as the RET suppression (Furlan et al. 2013).

Different from the embryonic maintenance of cholinergic properties by RET signaling, the postnatal trans-differentiation of noradrenergic sympathetic neurons in mammalian sweat glands towards a cholinergic transmitter phenotype is not mediated by RET but relies on gp130 signaling as shown in rat and mice (Habecker et al. 1997; Stanke et al. 2006). Growth factors binding to this receptor system also mediate sweat gland maturation in humans as inferred from the cold-induced sweating syndrome in homozygous mutations of the receptor (Melone et al. 2014; Oxford 2016). The postnatal trans-differentiation 
of initially noradrenergic neurons to cholinergic neurons innervating bone (Asmus et al. 2000) molecularly appears to rely on a different signaling system (Asmus et al. 2001) by a yet undefined growth factor.

Characterization of the neuron classes in adult mouse stellate and thoracic sympathetic ganglia by single cell RNA sequencing identified a range of molecularly distinct cell types (Furlan et al. 2016). This identified seven classes of efferent neurons, five with noradrenergic and two with cholinergic neurotransmitter characteristics which also show distinct growth factor receptor expression patterns. Two of these classes could be assigned to erector muscle neurons innervating piloerectors and nipple erector muscles which in the mature state express TRK A as well as RET. Organogenesis in the nipple and piloerector muscles occurs during the first postnatal days together with induction of RET expression and a marked soma size increase in the innervating neurons, indicating postnatal identity acquisition similar to sweat gland and bone innervating neurons, albeit without a change in the neurotransmitter phenotype. Differences in GFR alpha expression in cells destined to become nipple or piloerectors at an early postnatal time point preceding RET expression and final differentiation suggest the diversification of RET and GFR alpha expression as one critical path of sympathetic neuron differentiation next to the neurotransmitter phenotype.

The combination of genetic cell lineage tracing and single cell RNA sequencing now allows to considerably sharpen our idea about the nature of efferent sympathetic neuron classes. Data sets generated by this method also allow detailed analysis on the expression of voltage-gated ion channels, neurotransmitter receptors, and synaptic proteins to provide a picture of the information processing and propagating characteristics of the cell classes (Ernsberger et al. 2017). As detailed below, this method also provides access to data that may guide our thinking about the nature and development of target-specific sympathetic circuits.

\section{Formation of synaptic connections between pre- and postganglionic neurons in sympathetic ganglia: final step in the formation of target specific pathways}

The sympathetic ganglia are the relay sites where the central input undergoes a final processing operation when transmitted from the preganglionic neurons and translated to the efferent activity pattern recordable from the postganglionic neurons. In a classical set of electrophysiological analysis on superior cervical ganglion neurons from guinea pigs, estimates were derived on the numbers of preganglionics terminating onto individual postganglionic neurons which number to a minimum of 10 preganglionic neurons from four adjacent spinal cord segments converging onto one postganglionic neuron (Njå and Purves 1977; Purves and Wigston 1983). At the same time, one preganglionic neuron is estimated to contact approximately 50-200 postganglionic neurons, indicating the transmission of the activity status of one preganglionic neuron to a relatively large number of postganglionic neurons. Expectedly, these numbers differ between mammalian species (Lichtman and Purves 1980).

Importantly, there is a paring down in the number and distribution across spinal cord segments of preganglionic neurons converging onto one postganglionic cell during early postnatal life (Lichtman and Purves 1980). The observation that target deprivation or application of an NGF antiserum results in a reduced ganglionic transmission, and the number of synapse profiles on individual postganglionic neurons, which can be prevented by NGF administration ( $\mathrm{Njå}$ and Purves 1978), demonstrates the importance of target and target-derived factors on the innervation of postganglionic neurons by preganglionic fibers. It is reasonable to assume that the postnatal reduction in the convergence of preganglionic inputs to postganglionic sympathetic units and the regulation of the degree of convergence by the target share similar mechanisms.

The impact of nerve growth factor on the formation of synaptic specializations was confirmed in NGF mutant mice, where neuronal loss by cell death was prevented due to an additional BAX mutation (Sharma et al. 2010). NGF acts via binding to TRK $\mathrm{A}$, and its retrograde endosome transport into the dendrites is required for maintenance of a normal synaptic bouton complement (Lehigh et al. 2017). This process mediated by the target-derived growth factor NGF is complemented by preganglionic neuron-mediated communication via the neurotrophin BDNF that promotes synapse formation (Causing et al. 1997) which, in addition, is involved in axon pruning (Singh et al. 2008). Thus, 2 neurotrophins have been shown to be involved in the formation and maturation of the synaptic complement connecting preganglionic and postganglionic sympathetic neurons. The factors wiring different sympathetic target pathways in sympathetic ganglia by favoring the formation of synapses between selected preganglionic neurons and specific classes of postganglionic nerve cells or by removing connections between inappropriate neuron classes are unknown so far (Ernsberger and Rohrer 2018).

With the availability of the complete genome-wide RNA profiles of large numbers of sympathetic neurons, the search for neuron class-specific features opens new alleys to address the question for the molecular mediators of sympathetic pathway delineation (Table 2). In a large sample of mouse stellate and upper thoracic sympathetic neurons (Furlan et al. 2016), the characterization of seven classes of noradrenergic and cholinergic sympathetic neurons allowed the identification of cell adhesion and synaptic organizer molecules with remarkable neuron class-specific expression 
Table 2 Characterization of the neuronal elements and their connectivity involved in the formation of target-selective pathways in sympathetic ganglia

\begin{tabular}{|c|c|c|}
\hline Preganglionic input & Divergence/convergence & Postganglionic output \\
\hline \multirow[t]{6}{*}{$\begin{array}{l}16 \text { preganglionic classes in } \\
\text { mouse spinal cord (Blum et al. 2021) }\end{array}$} & $\begin{array}{l}1 \text { preggl. neuron contacts } 50 \text { to } 200 \\
\text { postggl cells; }\end{array}$ & \multirow{6}{*}{$\begin{array}{l}7 \text { postganglionic } \\
\text { classes } \\
\text { NA } 1 \text { to } 5 \text {, ACH } 1 \text {, and } \\
\text { ACH } 2 \text { in } \\
\text { mouse sympathetic } \\
\text { ganglia (Furlan et al. } \\
2016 \text { ) }\end{array}$} \\
\hline & $\begin{array}{l}1 \text { postggl. neuron receives minimal } 10 \\
\text { preggl inputs in guinea pig SCG }\end{array}$ & \\
\hline & $\begin{array}{l}\text { (Njå and Purves 1977; Purves and } \\
\text { Wigston 1983) }\end{array}$ & \\
\hline & $\begin{array}{l}1 \text { postggl neuron receives } 6-7 \text { preggl } \\
\text { inputs in adult; }\end{array}$ & \\
\hline & $\begin{array}{l}1 \text { postggl } \mathrm{n} \text {. receives more than } 11 \text { preggl } \\
\text { inputs in young hamster SCG }\end{array}$ & \\
\hline & (Lichtman and Purves 1980) & \\
\hline
\end{tabular}

Characterization of the preganglionic and postganglionic sympathetic neuron classes in mice was performed by single cell RNA sequencing. The number of preganglionic neuron classes identified by whole genome gene expression patterns from ChAT-positive spinal cord cells located at cervical to sacral levels exceeds the number of postganglionic neuron classes identified in the same manner from stellate and upper thoracic sympathetic ganglion cells

The characterization of the connectivity between pre- (preggl) and postganglionic (postggl) neurons in the guinea pig and hamster superior cervical ganglia was performed by intracellular recording. These studies show that individual preganglionic neurons innervate relatively large numbers of postganglionic cells. Individual postganglionic cells receive innervation by a comparatively small set of preganglionic neurons. This postganglionic innervation seems to become refined during development from young to mature animals patterns (Ernsberger et al. 2020; Fig. 2). While the mRNA expression levels for cell adhesion molecules like NCAM1 or L1CAM barely differ between the different sympathetic neuron classes, protocadherine 7, 9, and 17 mRNA levels differ between the neuron classes by more than tenfold, for PCDH7 to an extent similar to the highly specific marker genes vesicular monoamine transporter 2 and acetylcholine transporter.

In studies on genome-wide RNA profiles of mouse CHAT-positive spinal cord neurons including preganglionic sympathetic neurons, 16 classes of molecularly distinct preganglionic neuron types could be distinguished (Blum et al. 2021; Alkaslasi et al. 2021). Importantly, histograms of the relative mRNA expression levels of PCDH 7 versus 9 demarcated distinct relative expression quantities for each of the preganglionic neuron classes (http://spinalcordatlas. org). Since this molecular class has been involved in multiple steps of neural circuit formation based on homophilic interactions (Kim et al. 2011; Peek et al. 2017), its role in the formation of synaptic connections between preganglionic and postganglionic sympathetic neurons deserves experimental attention. The contribution to the etiology of neurodevelopmental disorders (Mancini et al. 2020) may not be restricted to higher-order cognitive disturbances.

\section{Concluding outlook}

The amazing advancements in understanding of the cellular structure and developmental generation of the sympathetic nervous system now allows to investigate the generation of target-specific efferent pathways. The identification of the molecular players regulating formation of the appropriate synaptic connections in sympathetic ganglia is one of the most exciting imminent questions regarding the development of the autonomic nervous system. At the same time, autonomic dysfunctions and alterations in the development of the sympathetic nervous system remain an immense or even increasing clinical challenge.

The urgent need for new therapies for childhood tumors (Zafar et al. 2021) puts emphasis on the improved understanding of the transition from cycling progenitors to mitotic inactive cells. This incompletely understood developmental progression in neural crest and sympathetic progenitors and neuroblasts holds a range of pressing questions. On the one hand, the unfolding of nuclear chromatin during segregation of noradrenergic and cholinergic neurotransmitter phenotypes together with the acquisition of a pan-neuronal transcriptome is still not fully understood. In addition and maybe even more important, the regulation of the overall mitotic cycle number in sympathetic neuroblasts and the molecular triggers for final mitotic withdrawal are still open (Chan et al. 2018). Rapidly progressing investigation in this field is expected to provide answer to these fundamental questions and will likely yield improved neuroblastoma therapy options (Durinck and Speleman 2018; Fetahu and TaschnerMandl 2021).

The diverse spectrum of disease-associated autonomic dysfunctions is the subject of autonomic medicine (Goldstein 2017). While the challenges in many areas are increasing, new diagnostic and therapeutic options become apparent. Progress in peripheral neural interface technology will 
improve bioelectronic neuromodulation and will refine this avenue of fighting defined, organ-selective dysregulation (Cho et al. 2020). Next to direct neuromodulatory intervention, electronic health applications will restructure the monitoring and surveillance of individual health conditions (Scholz et al. 2021; Cheshire et al. 2020). The possibility of self-monitoring outside the hospital will change access of patients to their diseases and will open a new chapter in personalized medicine.

Acknowledgements The authors acknowledge the generous support by Mrs. Jutta Jaeger with formatting the references. UE gratefully acknowledges the major help by Mrs. Ute Wagner.

Funding Open Access funding enabled and organized by Projekt DEAL. HR is supported by the Wilhelm-Sander-Foundation. UE was supported by the Deutsche Forschungsgemeinschaft and the Hertie Foundation.

\section{Declarations}

Ethics approval This article does not contain any studies with human participants or animals performed by the authors.

Conflict of interest The authors declare no competing interests.

Open Access This article is licensed under a Creative Commons Attribution 4.0 International License, which permits use, sharing, adaptation, distribution and reproduction in any medium or format, as long as you give appropriate credit to the original author(s) and the source, provide a link to the Creative Commons licence, and indicate if changes were made. The images or other third party material in this article are included in the article's Creative Commons licence, unless indicated otherwise in a credit line to the material. If material is not included in the article's Creative Commons licence and your intended use is not permitted by statutory regulation or exceeds the permitted use, you will need to obtain permission directly from the copyright holder. To view a copy of this licence, visit http://creativecommons.org/licenses/by/4.0/.

\section{References}

Ahmed S, Hu R, Leete J, Layton AT (2019) Understanding sex differences in long-term blood pressure regulation: insights from experimental studies and computational modeling. Am J Physiol Heart Circ Physiol 316(5):H1113-H1123. https://doi.org/10. 1152/ajpheart.00035.2019 (Epub 15 Mar 2019)

Ahrén B, Veith RC, Taborsky GJ Jr (1987) Sympathetic nerve stimulation versus pancreatic norepinephrine infusion in the dog: 1). Effects on basal release of insulin and glucagon. Endocrinology 121(1):323-331. https://doi.org/10.1210/endo-121-1-323

Ali FR, Marcos D, Chernukhin I, Woods LM, Parkinson LM, Wylie LA, Papkovskaia TD, Davies JD, Carroll JS, Philpott A (2020) Dephosphorylation of the proneural transcription factor ASCL1 re-engages a latent post-mitotic differentiation program in neuroblastoma. Mol Cancer Res 18(12):1759-1766. https://doi.org/ 10.1158/1541-7786.MCR-20-0693 (Epub 12 Oct 2020)

Alkaslasi MR, Piccus ZE, Hareendran S, Silberberg H, Chen L, Zhang Y, Petros TJ, Le Pichon CE (2021) Single nucleus RNA-sequencing defines unexpected diversity of cholinergic neuron types in the adult mouse spinal cord. Nat Commun 12:2471

Almutairi B, Charlet J, Dallosso AR, Szemes M, Etchevers HC, Malik KTA, Brown KW (2019) Epigenetic deregulation of GATA3 in neuroblastoma is associated with increased GATA3 protein expression and with poor outcomes. Sci Rep 9(1):18934. https:// doi.org/10.1038/s41598-019-55382-6

Armstrong LE, Johnson EC (2018) water intake, water balance, and the elusive daily water requirement. Nutrients 10(12):1928. https:// doi.org/10.3390/nu10121928

Asmus SE, Parsons S, Landis SC (2000) Developmental changes in the transmitter properties of sympathetic neurons that innervate the periosteum. J Neurosci 20(4):1495-504. https://doi.org/10. 1523/JNEUROSCI.20-04-01495.2000

Asmus SE, Tian H, Landis SC (2001) Induction of cholinergic function in cultured sympathetic neurons by periosteal cells: cellular mechanisms. Dev Biol 235(1):1-11. https://doi.org/10.1006/ dbio.2001.0282

Averina VA, Othmer HG, Fink GD, Osborn JW (2015) A mathematical model of salt-sensitive hypertension: the neurogenic hypothesis. J Physiol 593(14):3065-3075. https://doi.org/10.1113/jphysiol. 2014.278317 (Epub 27 Oct 2014)

Bachetti T, Ceccherini I (2020) Causative and common PHOX2B variants define a broad phenotypic spectrum. Clin Genet 97(1):103113. https://doi.org/10.1111/cge.13633 (Epub 30 Aug 2019)

Bądzyńska B, Baranowska I, Sadowski J (2021) Further evidence against the role renal medullary perfusion in short-term control of arterial pressure in normotensive and mildly or overtly hypertensive rats. Pflugers Arch 473(4):623-631. https://doi.org/10. 1007/s00424-021-02534-1 (Epub 2 Mar 2021)

Balmain BN, Sabapathy S, Louis M, Morris NR (2018) Aging and thermoregulatory control: the clinical implications of exercising under heat stress in older individuals. Biomed Res Int 2018:8306154. https://doi.org/10.1155/2018/8306154. eCollection 2018

Bartness TJ, Liu Y, Shrestha YB, Ryu V (2014) Neural innervation of white adipose tissue and the control of lipolysis. Front Neuroendocrinol 35(4):473-493. https://doi.org/10.1016/j.yfrne.2014.04. 001 (Epub 13 Apr 2014)

Bataille C, Mauprivez C, Hä̈ E, Baroukh B, Brun A, Chaussain C, Marie PJ, Saffar JL, Cherruau M (2012) Different sympathetic pathways control the metabolism of distinct bone envelopes. Bone 50(5):1162-1172. https://doi.org/10.1016/j.bone.2012. 01.023 (Epub 2 Feb 2012)

Bayliss WM, Starling EH (1892) On some points in the innervation of the mammalian heart. J Physiol 13(5):407-418

Belayev LY, Palevsky PM (2014) The link between acute kidney injury and chronic kidney disease. Curr Opin Nephrol Hypertens 23(2):149-154. https://doi.org/10.1097/01.mnh.0000441051. 36783.f3

Bell BB, Rahmouni K (2016) Leptin as a mediator of obesity-induced hypertension. Curr Obes Rep 5(4):397-404. https://doi.org/10. 1007/s13679-016-0231-x

Bellinger DL, Felten SY, Collier TJ, Felten DL (1987) Noradrenergic sympathetic innervation of the spleen: IV. Morphometric analysis in adult and aged F344 rats. J Neurosci Res 18:55-63. [PubMed: 3682028]

Bellinger DL, Lorton D (2014) Autonomic regulation of cellular immune function. Auton Neurosci 182:15-41. https://doi.org/ 10.1016/j.autneu.2014.01.006 (Epub 8 Feb 2014)

Bellinger DL, Lorton D (2018) Sympathetic nerve hyperactivity in the spleen: causal for nonpathogenic-driven chronic immune-mediated inflammatory diseases (IMIDs)? Int J Mol Sci 19(4):1188. https:// doi.org/10.3390/ijms19041188

Bellinger DL, Millar BA, Perez S, Carter J, Wood C, ThyagaRajan S, Molinaro C, Lubahn C, Lorton D (2008) Sympathetic modulation 
of immunity: relevance to disease. Cell Immunol 252(1-2):2756. https://doi.org/10.1016/j.cellimm.2007.09.005. Epub 4 Mar 2008

Bernard C (1957) An introduction to the study of experimental medicine. 1865 . originally published in 1865 ; first English translation by Henry Copley Greene, published by Macmillan \& Co., Ltd. 1927; Dover edition

Bie P, Damkjaer M (2010) Comments on point:counterpoint: the dominant contributor to systemic hypertension: chronic activation of the sympathetic nervous system vs. activation of the intrarenal renin-angiotensin system. Hung jury? J Appl Physiol (1985) 109(6):2011. https://doi.org/10.1152/japplphysiol.01160.2010

Bie P, Evans RG (2017) Normotension, hypertension and body fluid regulation: brain and kidney. Acta Physiol (Oxf) 219(1):288-304. https://doi.org/10.1111/apha.12718 (Epub 19 Jun 2016)

Bjurholm A, Kreicbergs A, Terenius L, Goldstein M, Schultzberg M (1988) Neuropeptide Y-, tyrosine hydroxylase- and vasoactive intestinal polypeptide-immunoreactive nerve in bone and surrounding tissues. J Auton Nerv Syst 25:119-125 [PubMed: 2906951]

Blankestijn PJ, London G, Fliser D, Jager KJ, Lindholm B, Goldsmith D, Wiecek A, Suleymanlar G, Agarwal R, Ortiz A, Massy Z, Martinez-Castelao A, Covic A, Dekker FW, Zoccali C (2011) For European renal and cardiovascular medicine working group of the European renal association-European dialysis and transplant association (ERA-EDTA). Major pathways of the renocardiovascular link: the sympathetic and renin-angiotensin systems. Kidney Int Suppl 1(1):13-16. https://doi.org/10.1038/ kisup. 2011.3

Blaszkiewicz M, Willows JW, Johnson CP, Townsend KL (2019) The importance of peripheral nerves in adipose tissue for the regulation of energy balance. Biology (Basel) 8(1):10. https:// doi.org/10.3390/biology8010010

Blum JA, Klemm S, Shadrach JL, Guttenplan KA, Nakayama L, Kathiria A, Hoang PT, Gautier O, Kaltschmidt JA, Greenleaf WJ, Gitler AD (2021) Single-cell transcriptomic analysis of the adult mouse spinal cord reveals molecular diversity of autonomic and skeletal motor neurons. Nat Neurosci 24(4):572583. https://doi.org/10.1038/s41593-020-00795-0 (Epub 15 Feb 2021)

Boeva V, Louis-Brennetot C, Peltier A, Durand S, Pierre-Eugène C, Raynal V, Etchevers HC, Thomas S, Lermine A, DaudigeosDubus E, Geoerger B, Orth MF, Grünewald TGP, Diaz E, Ducos B, Surdez D, Carcaboso AM, Medvedeva I, Deller T, Combaret V, Lapouble E, Pierron G, Grossetête-Lalami S, Baulande S, Schleiermacher G, Barillot E, Rohrer H, Delattre O, JanoueixLerosey I (2017) Heterogeneity of neuroblastoma cell identity defined by transcriptional circuitries. Nat Genet 49(9):14081413. https://doi.org/10.1038/ng.3921 (Epub 24 Jul 2017)

Booth LC, May CN, Yao ST (2015) The role of the renal afferent and efferent nerve fibers in heart failure. Front Physiol 6:270. https:// doi.org/10.3389/fphys.2015.00270. eCollection 2015

Borovac JA, D’Amario D, Bozic J, Glavas D (2020) Sympathetic nervous system activation and heart failure: current state of evidence and the pathophysiology in the light of novel biomarkers. World J Cardiol 12(8):373-408. https://doi.org/10.4330/wjc.v12.i8.373

Brands MW (2012) Chronic blood pressure control. Compr Physiol 2(4):2481-2494. https://doi.org/10.1002/cphy.c100056

Braunwald E (2013) Heart failure. JACC Heart Fail 1(1):1-20. https:// doi.org/10.1016/j.jchf.2012.10.002 (Epub 4 Feb 2013)

Bronner-Fraser M (1995) Patterning of the vertebrate neural crest. Perspect Dev Neurobiol 3(1):53-62

Burau K, Stenull I, Huber K, Misawa H, Berse B, Unsicker K, Ernsberger $\mathrm{U}$ (2004) c-ret regulates cholinergic properties in mouse sympathetic neurons: evidence from mutant mice. Eur J Neurosci 20(2):353-62. https://doi.org/10.1111/j.1460-9568.2004.03500.x
Cane KN, Anderson CR (2009) Generating diversity: Mechanisms regulating the differentiation of autonomic neuron phenotypes. Auton Neurosci 151(1):17-29. https://doi.org/10.1016/j.autneu. 2009.08.010 (Epub 9 Oct 2009)

Cannon WB (1932) The Wisdom of the Body. W. W. Norton \& Company, New York, pp 177-201

Cannon B, Nedergaard J (2004) Brown adipose tissue: function and physiological significance. Physiol Rev 84(1):277-359. https:// doi.org/10.1152/physrev.00015.2003

Capasso M, Montella A, Tirelli M, Maiorino T, Cantalupo S, Iolascon A (2020) Genetic predisposition to solid pediatric cancers. Front Oncol 10:590033. https://doi.org/10.3389/fonc.2020.590033. eCollection 2020

Carcel C, Neal B, Oparil S, Rogers K, Narkiewicz K, Wang JG, Schiffrin EL, Poulter N, Azizi M, Chalmers J (2019) Clinical characteristics, antihypertensive medication use and blood pressure control among patients with treatment-resistant hypertension: the survey of patients with treatment resistant hypertension study. J Hypertens 37(11):2216-2224. https://doi.org/10.1097/ HJH.0000000000002184

Causing CG, Gloster A, Aloyz R, Bamji SX, Chang E, Fawcett J, Kuchel G, Miller FD (1997) Synaptic innervation density is regulated by neuron-derived BDNF. Neuron 18(2):257-267. https:// doi.org/10.1016/s0896-6273(00)80266-4

Chan WH, Anderson CR, Gonsalvez DG (2018) From proliferation to target innervation: signaling molecules that direct sympathetic nervous system development. Cell Tissue Res 372(2):171-193. https://doi.org/10.1007/s00441-017-2693-x (Epub 2 Oct 2017)

Charkoudian N (2010) Mechanisms and modifiers of reflex induced cutaneous vasodilation and vasoconstriction in humans. J Appl Physiol 109(4):1221-1228. https://doi.org/10.1152/japplphysiol. 00298.2010. Epub 6 May 2010

Cheshire WP, Freeman R, Gibbons CH, Cortelli P, Wenning GK, Hilz MJ, Spies JM, Lipp A, Sandroni P, Wada N, Mano A, Ah Kim H, Kimpinski K, Iodice V, Idiáquez J, Thaisetthawatkul P, Coon EA, Low PA, Singer W (2021) Electrodiagnostic assessment of the autonomic nervous system: a consensus statement endorsed by the American Autonomic Society, American Academy of Neurology, and the International Federation of Clinical Neurophysiology. Clin Neurophysiol 132(2):666-682. https://doi.org/ 10.1016/j.clinph.2020.11.024 (Epub 22 Dec 2020)

Chiera M, Cerritelli F, Casini A, Barsotti N, Boschiero D, Cavigioli F, Corti CG, Manzotti A (2020) Heart rate variability in the perinatal period: a critical and conceptual review. Front Neurosci 14:561186. https:// doi.org/10.3389/fnins.2020.561186. eCollection 2020

Cho Y, Park J, Lee C, Lee S (2020) Recent progress on peripheral neural interface technology towards bioelectronic medicine. Bioelectron Med 6(1):23. https://doi.org/10.1186/s42234-020-00059-z

Contreras C, Nogueiras R, Diéguez C, Rahmouni K, López M (2017) Traveling from the hypothalamus to the adipose tissue: the thermogenic pathway. Redox Biol 12:854-863. https://doi.org/10. 1016/j.redox.2017.04.019 (Epub 15 Apr 2017)

Coppola E, d'Autréaux F, Rijli FM, Brunet JF (2010) Ongoing roles of Phox2 homeodomain transcription factors during neuronal differentiation. Development 137(24):4211-20. https://doi.org/ 10.1242/dev.056747 (Epub 10 Nov 2010)

del Toro R, Méndez-Ferrer S (2013) Autonomic regulation of hematopoiesis and cancer. Haematologica 98(11):1663-6. https://doi. org/10.3324/haematol.2013.084764

DiBona GF (2000) Neural control of the kidney: functionally specific renal sympathetic nerve fibers. Am J Physiol Regul Integr Comp Physiol 279(5):R1517-R1524. https://doi.org/10.1152/ajpregu. 2000.279.5.R1517

DiBona GF, Kopp UC (1997) Neural control of renal function. Physiol Rev 77(1):75-197. https://doi.org/10.1152/physrev.1997.77.1.75 
Dorrington KL, Pandit JJ (2009) The obligatory role of the kidney in long-term arterial blood pressure control: extending Guyton's model of the circulation. Anaesthesia 64(11):1218-28. https:// doi.org/10.1111/j.1365-2044.2009.06052.x

Ducy P, Amling M, Takeda S, Priemel M, Schilling AF, Beil FT, Shen J, Vinson C, Rueger JM, Karsenty G (2000) Leptin inhibits bone formation through a hypothalamic relay: a central control of bone mass. Cell 100(2):197-207. https://doi.org/10.1016/ s0092-8674(00)81558-5

Durinck K, Speleman F (2018) Epigenetic regulation of neuroblastoma development. Cell Tissue Res 372(2):309-324. https://doi.org/ 10.1007/s00441-017-2773-y (Epub 19 Jan 2018)

Elefteriou F (2018) Impact of the autonomic nervous system on the skeleton. Physiol Rev 98(3):1083-1112. https://doi.org/10.1152/ physrev.00014.2017

Elefteriou F, Ahn JD, Takeda S, Starbuck M, Yang X, Liu X, Kondo H, Richards WG, Bannon TW, Noda M, Clement K, Vaisse C, Karsenty G (2005) Leptin regulation of bone resorption by the sympathetic nervous system and CART. Nature 434(7032):514-520. https://doi.org/10.1038/ nature03398 (Epub 20 Feb 2005)

Elenkov IJ, Wilder RL, Chrousos GP, Vizi ES (2000) The sympathetic nerve-an integrative interface between two supersystems: the brain and the immune system. Pharmacol Rev 52(4):595-638

Ernsberger U (2000) Evidence for an evolutionary conserved role of bone morphogenetic protein growth factors and phox 2 transcription factors during noradrenergic differentiation of sympathetic neurons. Induction of a putative synexpression group of neurotransmitter-synthesizing enzymes. Eur J Biochem 267(24):69766981. https://doi.org/10.1046/j.1432-1327.2000.01827.x

Ernsberger U, Deller T, Rohrer H (2020) The diversity of neuronal phenotypes in rodent and human autonomic ganglia. Cell Tissue Res 382(2):201-231. https://doi.org/10.1007/s00441-020-032796 (Epub 15 Sep 2020 PMID: 32930881)

Ernsberger U, Kramer M, Tsarovina K, Deller T, Rohrer H (2017) Coordinate expression of pan-neuronal and functional signature genes in sympathetic neurons. Cell Tissue Res 370(2):227-241. https://doi.org/10.1007/s00441-017-2688-7 (Epub 21 Sep 2017)

Ernsberger U, Patzke H, Rohrer H (1997) The developmental expression of choline acetyltransferase (ChAT) and the neuropeptide VIP in chick sympathetic neurons: evidence for different regulatory events in cholinergic differentiation. Mech Dev 68(12):115-126. https://doi.org/10.1016/s0925-4773(97)00135-4

Ernsberger U, Rohrer H (2018) Sympathetic tales: subdivisons of the autonomic nervous system and the impact of developmental studies. Neural Dev 13(1):20. https://doi.org/10.1186/ s13064-018-0117-6

Esler M (2010) The 2009 Carl Ludwig lecture: pathophysiology of the human sympathetic nervous system in cardiovascular diseases: the transition from mechanisms to medical management. J Appl Physiol (1985) 108(2):227-237. https://doi.org/10.1152/japplphysiol.00832. 2009. Epub 25 Nov 2009

Esler M, Kaye D (1998) Increased sympathetic nervous system activity and its therapeutic reduction in arterial hypertension, portal hypertension and heart failure. J Auton Nerv Syst 72(2-3):210219. https://doi.org/10.1016/s0165-1838(98)00107-6

Esler M, Lambert E, Schlaich M (2010) Point: Chronic activation of the sympathetic nervous system is the dominant contributor to systemic hypertension. J Appl Physiol (1985) 109(6):1996-1998; discussion 2016. https://doi.org/10.1152/japplphysiol.00182. 2010. Epub 25 Feb 2010

Fagan AM, Zhang H, Landis S, Smeyne RJ, Silos-Santiago I, Barbacid M (1996) TrkA, but not TrkC, receptors are essential for survival of sympathetic neurons in vivo. J Neurosci 16(19):6208-6218. https://doi.org/10.1523/JNEUROSCI.16-19-06208.1996
Felten DL, Felten SY (1989) Innervation of the thymus. In: Kendal MD, Ritter MA (eds) Thymus Update. Harwood Academic Publishers, London, pp 73-88

Felten SY, Felten DL (1991) The innervation of lymphoid tissue. In: Ader R, Felten DL, Cohen N (eds) Psychoneuroimmunology, 2nd edn. Academic Press, New York, pp 27-69

Fetahu IS, Taschner-Mandl S (2021) Neuroblastoma and the epigenome. Cancer Metastasis Rev 40(1):173-189. https://doi.org/ 10.1007/s10555-020-09946-y (Epub 6 Jan 2021)

Fielding C, Méndez-Ferrer S (2020) Neuronal regulation of bone marrow stem cell niches. F1000Res 9:F1000 Faculty Rev 614. https://doi. org/10.12688/f1000research.22554.1. eCollection 2020

Fillenz M (1970) The innervation of the cat spleen. Proc R Soc Lond B Biol Sci. 1970 Jan 20;174(1037):459-68. https://doi.org/10.1098/ rspb. 1970.0005

Floras JS (2009) Sympathetic nervous system activation in human heart failure: clinical implications of an updated model. J Am Coll Cardiol 54(5):375-385. https://doi.org/10.1016/j.jacc.2009.03.061

Floras JS, Ponikowski P (2015) The sympathetic/parasympathetic imbalance in heart failure with reduced ejection fraction. Eur Heart J 36(30):1974-1982. https://doi.org/10.1093/eurheartj/ ehv087 (Epub 13 May 2015)

Francis NJ, Landis SC (1999) Cellular and molecular determinants of sympathetic neuron development. Annu Rev Neurosci 22:541566. https://doi.org/10.1146/annurev.neuro.22.1.541

Francisco MA, Minson CT (2018) Cutaneous active vasodilation as a heat loss thermoeffector. Handb Clin Neurol 156:193-209. https://doi.org/10.1016/B978-0-444-63912-7.00012-6

Frith TJR, Tsakiridis A (2019) Efficient generation of trunk neural crest and sympathetic neurons from human pluripotent stem cells via a neuromesodermal axial progenitor intermediate. Curr Protoc Stem Cell Biol 49(1):e81. https://doi.org/10.1002/cpsc.81. Epub 28 Jan 2019

Furlan A, Dyachuk V, Kastriti ME, Calvo-Enrique L, Abdo H, Hadjab S, Chontorotzea T, Akkuratova N, Usoskin D, Kamenev D, Petersen J, Sunadome K, Memic F, Marklund U, Fried K, Topilko P, Lallemend F, Kharchenko PV, Ernfors P, Adameyko I (2017) Multipotent peripheral glial cells generate neuroendocrine cells of the adrenal medulla. Science 357(6346):eaal3753. https://doi.org/10.1126/science.aal3753

Furlan A, La Manno G, Lübke M, Häring M, Abdo H, Hochgerner H, Kupari J, Usoskin D, Airaksinen MS, Oliver G, Linnarsson S, Ernfors P (2016) Visceral motor neuron diversity delineates a cellular basis for nipple- and pilo-erection muscle control. Nat Neurosci 19(10):1331-1340. https://doi.org/10.1038/nn.4376 (Epub 29 Aug 2016)

Furlan A, Lübke M, Adameyko I, Lallemend F, Ernfors P (2013) The transcription factor $\mathrm{Hmx} 1$ and growth factor receptor activities control sympathetic neurons diversification. EMBO J 32(11):1613-1625. https://doi.org/10.1038/emboj.2013.85 (Epub 16 Apr 2013)

Gagnon D, Jay O, Kenny GP (2013) The evaporative requirement for heat balance determines whole-body sweat rate during exercise under conditions permitting full evaporation. J Physiol 591(11):2925-2935. https://doi.org/10.1113/jphysiol.2012. 248823 (Epub 4 Mar 2013)

García-García A, Korn C, García-Fernández M, Domingues O, Villadiego J, Martín-Pérez D, Isern J, Bejarano-García JA, Zimmer J, PérezSimón JA, Toledo-Aral JJ, Michel T, Airaksinen MS, MéndezFerrer S (2019) Dual cholinergic signals regulate daily migration of hematopoietic stem cells and leukocytes. Blood 133(3):224-236. https://doi.org/10.1182/blood-2018-08-867648 (Epub 25 Oct 2018)

Goldstein DS (2017) Principles of autonomic medicine; https://www. multiplesystematrophy.org/wp-content/uploads/2017/09/Principlesof-Autonomic-Medicine-v.-2.1-11-28-16.pdf 
Goldstein DS (2019) 2019, How does homeostasis happen? Integrative physiological, systems biological, and evolutionary perspectives. Am J Physiol Regul Integr Comp Physiol 316(4):R301-R317. https://doi.org/10.1152/ajpregu.00396.2018 (Epub 16 Jan 2019)

Gonsalvez DG, Cane KN, Landman KA, Enomoto H, Young HM, Anderson CR (2013) Proliferation and cell cycle dynamics in the developing stellate ganglion. J Neurosci 33(14):5969-5979. https://doi.org/10.1523/JNEUROSCI.4350-12.2013

Graja A, Schulz TJ (2015) Mechanisms of aging-related impairment of brown adipocyte development and function. Gerontology 61(3):211217. https://doi.org/10.1159/000366557 (Epub 20 Dec 2014)

Gravel H, Chaseling GK, Barry H, Debray A, Gagnon D (2021) Cardiovascular control during heat stress in older adults: time for an update. Am J Physiol Heart Circ Physiol 320(1):H411-H416. https://doi.org/10.1152/ajpheart.00536.2020 (Epub 4 Dec 2020)

Greaney JL, Alexander LM, Kenney WL (2015) Sympathetic control of reflex cutaneous vasoconstriction in human aging. J Appl Physiol (1985) 119(7):771-782. https://doi.org/10.1152/japplphysiol. 00527.2015. Epub 13 Aug 2015

Groves AK, George KM, Tissier-Seta JP, Engel JD, Brunet JF, Anderson DJ (1995) Differential regulation of transcription factor gene expression and phenotypic markers in developing sympathetic neurons. Development 121(3):887-901

Guyenet PG (2006) The sympathetic control of blood pressure. Nat Rev Neurosci 7(5):335-346. https://doi.org/10.1038/nrn1902

Guyton AC (1990) Renal function curves and control of body fluids and arterial pressure. Acta Physiol Scand Suppl 591:107-113

Guyton AC, Coleman TG, Granger HJ (1972) Circulation: overall regulation. Annu Rev Physiol 34:13-46. https://doi.org/10.1146/ annurev.ph.34.030172.000305

Habecker BA, Symes AJ, Stahl N, Francis NJ, Economides A, Fink JS, Yancopoulos GD, Landis SC (1997) A sweat gland-derived differentiation activity acts through known cytokine signaling pathways. J Biol Chem 272(48):30421-30428. https://doi.org/ 10.1074/jbc.272.48.30421

Häbler HJ, Jänig W, Michaelis M (1994) Respiratory modulation in the activity of sympathetic neurones. Prog Neurobiol 43(6):567-606. https://doi.org/10.1016/0301-0082(94)90053-1

Hall JE, do Carmo JM, da Silva AA, Wang Z, Hall ME (2019) Obesity, kidney dysfunction and hypertension: mechanistic links. Nat Rev Nephrol 15(6):367-385. https://doi.org/10.1038/s41581-019-0145-4

Harms MPM, Finucane C, Pérez-Denia L, Juraschek SP, van Wijnen VK, Lipsitz LA, van Lieshout JJ, Wieling W (2021) Systemic and cerebral circulatory adjustment within the first $60 \mathrm{~s}$ after active standing: An integrative physiological view. Auton Neurosci 231:102756. https://doi.org/10.1016/j.autneu.2020.102756 (Epub 10 Dec 2020)

Hart EC, Charkoudian N (2014) Sympathetic neural regulation of blood pressure: influences of sex and aging. Physiology (Bethesda) 29(1):8-15. https://doi.org/10.1152/physiol.00031.2013

Hiltunen PH, Airaksinen MS (2004) Sympathetic cholinergic target innervation requires GDNF family receptor GFR alpha 2 . Mol Cell Neurosci 26(3):450-457. https://doi.org/10.1016/j.mcn. 2004.04.003

Huang M, Miller ML, McHenry LK, Zheng T, Zhen Q, Ilkhanizadeh S, Conklin BR, Bronner ME, Weiss WA (2016) Generating trunk neural crest from human pluripotent stem cells. Sci Rep 27(6):19727. https://doi.org/10.1038/srep19727

Huang T, Hu J, Wang B, Nie Y, Geng J, Cheng L (2013) Tlx3 controls cholinergic transmitter and Peptide phenotypes in a subset of prenatal sympathetic neurons. J Neurosci 33(26):10667-10675. https://doi.org/10.1523/JNEUROSCI.0192-13.2013

Huber K, Ernsberger U (2006) Cholinergic differentiation occurs early in mouse sympathetic neurons and requires Phox2b. Gene Expr 13(2):133-139. https://doi.org/10.3727/000000006783991854
Idiaquez JF, Idiaquez J, Casar JC, Biaggioni I (2021) Neurogenic orthostatic hypotension. Lessons from synucleinopathies. Am J Hypertens 34(2):125-133. https://doi.org/10.1093/ajh/hpaa131

Iriki M, Simon E (2012) Differential control of efferent sympathetic activity 2012. J Physiol Sci 62(4):275-298. https://doi.org/10. 1007/s12576-012-0208-9

Jafari LA, Suen RM, Khan SS (2020) Refocusing on the primary prevention of heart failure. Curr Treat Options Cardiovasc Med 22(7):13. https:// doi.org/10.1007/s11936-020-00811-3. Epub 29 May 2020

Jänig W (2006) The integrative action of the autonomic nervous system: neurobiology of homeostasis. Cambridge University Press, Cambridge

Jänig W, Häbler HJ (2000) Specificity in the organization of the autonomic nervous system: a basis for precise neural regulation of homeostatic and protective body functions. Prog Brain Res 122:351-367. https://doi.org/10.1016/s0079-6123(08)62150-0

Jänig W, McLachlan EM (1992) Characteristics of function-specific pathways in the sympathetic nervous system. Trends Neurosci 15(12):475-481. https://doi.org/10.1016/0166-2236(92) 90092-m

Jansky S, Sharma AK, Körber V et al (2021) Single-cell transcriptomic analyses provide insights into the developmental origins of neuroblastoma. Nat Genet 53:683-693. https://doi-org.proxy.insermbiblio. inist.fr/, https://doi.org/10.1038/s41588-021-00806-1

Johns EJ (2013) Autonomic regulation of kidney function. Handb Clin Neurol 117:203-214. https://doi.org/10.1016/B978-0-44453491-0.00017-1

Johns EJ, Kopp UC, DiBona GF (2011) Neural control of renal function. Compr Physiol 1(2):731-767. https://doi.org/10.1002/cphy. c100043

Johnsen JI, Dyberg C, Wickström M (2019) Neuroblastoma-A neural crest derived embryonal malignancy. Front Mol Neurosci 12:9 https://doi.org/10.3389/fnmol.2019.00009. eCollection 2019

Johnson JM, Minson CT, Kellogg DL Jr (2014) Cutaneous vasodilator and vasoconstrictor mechanisms in temperature regulation. Compr Physiol 4(1):33-89. https://doi.org/10.1002/cphy.c130015

Kalcheim C (2018) Neural crest emigration: from start to stop. Genesis 56(6-7):e23090. https://doi.org/10.1002/dvg.23090. Epub 25 Jan 2018

Kalil GZ, Haynes WG (2012) Sympathetic nervous system in obesityrelated hypertension: mechanisms and clinical implications. Hypertens Res 35(1):4-16. https://doi.org/10.1038/hr.2011.173 (Epub 3 Nov 2011)

Kameneva P, Artemov AV, Kastriti ME, Faure L, Olsen TK, Otte J, Erickson A, Semsch B, Andersson ER, Ratz M, Frisén J, Tischler AS, de Krijger RR, Bouderlique T, Akkuratova N, Vorontsova M, Gusev O, Fried K, Sundström E, Mei S, Kogner P, Baryawno N, Kharchenko PV, Adameyko I (2021) Single-cell transcriptomics of human embryos identifies multiple sympathoblast lineages with potential implications for neuroblastoma origin. Nat Genet 53(5):694-706. https://doi.org/10.1038/s41588-021-00818-x (Epub 8 Apr 2021)

Kang KW, Ok M, Lee SK (2020) Leptin as a Key between obesity and cardiovascular disease. J Obes Metab Syndr. 29(4):248-259. https://doi.org/10.7570/jomes20120

Karaaslan F, Denizhan Y, Hester R (2014) A mathematical model of long-term renal sympathetic nerve activity inhibition during an increase in sodium intake. hAm J Physiol Regul Integr Comp Physiol 306(4):R234-R247. https://doi.org/10.1152/ajpregu. 00302.2012. (Epub 27 Nov2013)

Karaaslan F, Denizhan Y, Kayserilioglu A, Gulcur HO (2005) Long-term mathematical model involving renal sympathetic nerve activity, arterial pressure, and sodium excretion. Ann Biomed Eng 33(11):1607-1630. https://doi.org/10.1007/ s10439-005-5976-4 
Kastriti ME, Kameneva P, Kamenev D, Dyachuk V, Furlan A, Hampl M, Memic F, Marklund U, Lallemend F, Hadjab S, CalvoEnrique L, Ernfors P, Fried K, Adameyko I (2019) Schwann cell precursors generate the majority of chromaffin cells in Zuckerkandl organ and some sympathetic neurons in paraganglia. Front Mol Neurosci 12:6. https://doi.org/10.3389/fnmol.2019.00006. eCollection 2019

Katayama Y, Battista M, Kao WM, Hidalgo A, Peired AJ, Thomas SA, Frenette PS (2006) Signals from the sympathetic nervous s126. ystem regulate hematopoietic stem cell egress from bone marrow. Cell 124(2):407-421. https://doi.org/10.1016/j.cell.2005.10.041

Kellogg DL Jr (2006) In vivo mechanisms of cutaneous vasodilation and vasoconstriction in humans during thermoregulatory challenges. J Appl Physiol 100(5):1709-1718. https://doi.org/10. 1152/japplphysiol.01071.2005

Kelly KL (1976) Beta blockers in hypertension: a review. Am J Hosp Pharm 33(12):1284-1290

Kenney WL (1985) A review of comparative responses of men and women to heat stress. Environ Res 37(1):1-11. https://doi.org/ 10.1016/0013-9351(85)90044-1

Kenney WL, Craighead DH, Alexander LM (2014) Heat waves, aging, and human cardiovascular health. Med Sci Sports Exerc 46(10):18911899. https://doi.org/10.1249/MSS.0000000000000325

Kenny GP, McGinn R (2017) Restoration of thermoregulation after exercise. J Appl Physiol (1985) 122(4):933-944. https://doi. org/10.1152/japplphysiol.00517.2016. Epub 23 Nov 2016

Keywan C, Poduri AH, Goldstein RD, Holm IA (2021) Genetic factors underlying sudden infant death syndrome. Appl Clin Genet 14:6176. https://doi.org/10.2147/TACG.S239478. eCollection 2021

Kim SY, Yasuda S, Tanaka H, Yamagata K, Kim H (2011) Nonclustered protocadherin. Cell Adh Migr 5(2):97-105. https:// doi.org/10.4161/cam.5.2.14374. (Epub 1 Mar 2011)

Koizumi K, Kollai M (1992) Multiple modes of operation of cardiac autonomic control: development of the ideas from Cannon and brooks to the present. J Auton Nerv Syst 41(1-2):19-29

Kollai M, Koizumi K (1979) Reciprocal and non-reciprocal action of the vagal and sympathetic nerves innervating the heart. J Auton Nerv Syst 1(1):33-52

Kulesa PM, Lefcort F, Kasemeier-Kulesa JC (2009) The migration of autonomic precursor cells in the embryo. Auton Neurosci 151(1):3-9. https://doi.org/10.1016/j.autneu.2009.08.013 (Epub 23 Sep 2009)

Langley JN (1921) The autonomic nervous system (Pt 1). W. Heffer \& Sons Ltd., Cambridge

Larabee CM, Neely OC, Domingos AI (2020) Obesity: a neuroimmunometabolic perspective. Nat Rev Endocrinol 16(1):30-43. https://doi.org/10.1038/s41574-019-0283-6 (Epub 27 Nov 2019)

Lehigh KM, West KM, Ginty DD (2017) Retrogradely transported TrkA endosomes signal locally within dendrites to maintain sympathetic neuron synapses. Cell Rep 19(1):86-100. https:// doi.org/10.1016/j.celrep.2017.03.028

Levi-Montalcini R (1987) The nerve growth factor 35 years later. Science 237(4819):1154-1162. https://doi.org/10.1126/science. 3306916

Levi-Montalcini R, Hamburger V (1951) Selective growth stimulating effects of mouse sarcoma on the sensory and sympathetic nervous system of the chick embryo. J Exp Zool 116(2):321361. https://doi.org/10.1002/jez.1401160206

Levy D, Kenchaiah S, Larson MG, Benjamin EJ, Kupka MJ, Ho KK, Murabito JM, Vasan RS (2002) Long-term trends in the incidence of and survival with heart failure. N Engl J Med 347(18):1397-1402. https://doi.org/10.1056/NEJMoa020265

Levy D, Larson MG, Vasan RS, Kannel WB, Ho KK (1996) The progression from hypertension to congestive heart failure. JAMA 275(20):1557-1562
Lichtman JW, Purves D (1980) The elimination of redundant preganglionic innervation to hamster sympathetic ganglion cells in early post-natal life. J Physiol 301:213-228. https://doi.org/ 10.1113/jphysiol.1980.sp013200

Lin EE, Scott-Solomon E, Kuruvilla R (2021) Peripheral innervation in the regulation of glucose homeostasis. Trends Neurosci 44(3):189-202. https://doi.org/10.1016/j.tins.2020.10.015 (Epub 20 Nov 2020)

Lori A, Perrotta M, Lembo G, Carnevale D (2017) The spleen: a hub connecting nervous and immune systems in cardiovascular and metabolic diseases. Int J Mol Sci 18(6):1216. https://doi.org/ 10.3390/ijms 18061216

Madden CJ, Morrison SF (2019) Central nervous system circuits that control body temperature. Neurosci Lett 23(696):225-232. https://doi.org/10.1016/j.neulet.2018.11.027 (Epub 23 Dec 2018)

Mancini M, Bassani S, Passafaro M (2020) Right place at the right time: how changes in protocadherins affect synaptic connections contributing to the etiology of neurodevelopmental disorders. Cells 9(12):2711. https://doi.org/10.3390/cells9122711

Mark AL, Rahmouni K, Correia M, Haynes WG (2003) A leptin-sympathetic-leptin feedback loop: potential implications for regulation of arterial pressure and body fat. Acta Physiol Scand 177(3):345-349. https://doi.org/10.1046/j.1365-201X.2003.01085.x

Martin N, Manoharan K, Thomas J, Davies C, Lumbers RT (2018) Beta-blockers and inhibitors of the renin-angiotensin aldosterone system for chronic heart failure with preserved ejection fraction. Cochrane Database Syst Rev 6(6):CD012721. https://doi.org/10. 1002/14651858.CD012721.pub2

McAllen RM, McKinley MJ (2018) Efferent thermoregulatory pathways regulating cutaneous blood flow and sweating. Handb Clin Neurol 156:305-316. https://doi.org/10.1016/B978-0-44463912-7.00018-7

Mecawi Ade S, Ruginsk SG, Elias LL, Varanda WA, Antunes-Rodrigues J (2015) Neuroendocrine regulation of hydromineral homeostasis. Compr Physiol 5(3):1465-516. https://doi.org/10.1002/cphy.c140031

Melone MA, Pellegrino MJ, Nolano M, Habecker BA, Johansson S, Nathanson NM, Knappskog PM, Hahn AF, Boman H (2014) Unusual Stüve-Wiedemann syndrome with complete maternal chromosome 5 isodisomy. Ann Clin Transl Neurol 1(11):926932. https://doi.org/10.1002/acn3.126 (Epub 24 Oct 2014)

Molkov YI, Zoccal DB, Baekey DM, Abdala AP, Machado BH, Dick TE, Paton JF, Rybak IA (2014) Physiological and pathophysiological interactions between the respiratory central pattern generator and the sympathetic nervous system. Prog Brain Res 212:1-23. https://doi.org/10.1016/B978-0-444-63488-7.00001-X

Montani JP, Van Vliet BN (2009) Understanding the contribution of Guyton's large circulatory model to long-term control of arterial pressure. Exp Physiol 94(4):382-388. https://doi.org/10.1113/ expphysiol.2008.043299

Moore MC, Coate KC, Winnick JJ, An Z, Cherrington AD (2012) Regulation of hepatic glucose uptake and storage in vivo. Adv Nutr 3(3):286-294. https://doi.org/10.3945/an.112.002089

Moriguchi T (2021) Development and carcinogenesis: roles of GATA factors in the sympathoadrenal and urogenital systems. Biomedicines 9(3):299. https://doi.org/10.3390/biomedicines9030299

Morrison SF (2001) Differential control of sympathetic outflow. Am J Physiol Regul Integr Comp Physiol 281(3):R683-R698. https:// doi.org/10.1152/ajpregu.2001.281.3.R683

Nakamura Y, Nakamura K (2018) Central regulation of brown adipose tissue thermogenesis and energy homeostasis dependent on food availability. Pflugers Arch 470(5):823-837. https://doi.org/10. 1007/s00424-017-2090-z (Epub 5 Dec 2017)

Nance DM, Sanders VM (2007) Autonomic innervation and regulation of the immune system (1987-2007). Brain Behav Immun 21(6):736745. https://doi.org/10.1016/j.bbi.2007.03.008 (Epub 27 Apr 2007) 
Navar LG (2010) Counterpoint: Activation of the intrarenal renin-angiotensin system is the dominant contributor to systemic hypertension. J Appl Physiol (1985) 109(6): 1998-2000; discussion 2015. https://doi.org/10.1152/japplphysiol.00182.2010a

Nicolini P, Ciulla MM, De Asmundis C, Magrini F, Brugada P (2012) The prognostic value of heart rate variability in the elderly, changing the perspective: from sympathovagal balance to chaos theory. Pacing Clin Electrophysiol 35(5):622-638. https://doi. org/10.1111/j.1540-8159.2012.03335.x (Epub 21 Feb 2012)

Njå A, Purves D (1977) Specific innervation of guinea-pig superior cervical ganglion cells by preganglionic fibres arising from different levels of the spinal cord. J Physiol 264(2):565-583. https:// doi.org/10.1113/jphysiol.1977.sp011683

Njå A, Purves D (1978) The effects of nerve growth factor and its antiserum on synapses in the superior cervical ganglion of the guinea-pig. J Physiol 277:53-75

Nochioka K, Sakata Y, Shimokawa H (2018) Combination therapy of renin angiotensin system inhibitors and $\beta$-blockers in patients with heart failure. Adv Exp Med Biol 1067:17-30. https://doi. org/10.1007/5584_2018_179

Noh MR, Jang HS, Kim J, Padanilam BJ (2020) Renal sympathetic nerve-derived signaling in acute and chronic kidney diseases. Int J Mol Sci 21(5):1647. https://doi.org/10.3390/ijms21051647

Pattyn A, Morin X, Cremer H, Goridis C, Brunet JF (1999) The homeobox gene Phox $2 \mathrm{~b}$ is essential for the development of autonomic neural crest derivatives. Nature 399(6734):366-370. https://doi. org/10.1038/20700

Oh Y, Cho GS, Li Z, Hong I, Zhu R, Kim MJ, Kim YJ, Tampakakis E, Tung L, Huganir R, Dong X, Kwon C, Lee G (2016) Functional coupling with cardiac muscle promotes maturation of hPSCderived sympathetic neurons. Cell Stem Cell 19(1):95-106. https://doi.org/10.1016/j.stem.2016.05.002 (Epub 16 Jun 2016)

Oppenheim RW (1989) The neurotrophic theory and naturally occurring motoneuron death. Trends Neurosci 12(7):252-255. https:// doi.org/10.1016/0166-2236(89)90021-0

Osborn JW, Averina VA, Fink GD (2009) Current computational models do not reveal the importance of the nervous system in longterm control of arterial pressure. Exp Physiol 94(4):389-396. https://doi.org/10.1113/expphysiol.2008.043281

Osborn JW, Jacob F, Guzman P (2005) A neural set point for the longterm control of arterial pressure: beyond the arterial baroreceptor reflex. Am J Physiol Regul Integr Comp Physiol 288(4):R846855. https://doi.org/10.1152/ajpregu.00474.2004

Osborn JW, Tyshynsky R, Vulchanova L (2021) Function of renal nerves in kidney physiology and pathophysiology. Annu Rev Physiol 10(83):429-450. https://doi.org/10.1146/annurevphysiol-031620-091656

Otto E, Knapstein PR, Jahn D, Appelt J, Frosch KH, Tsitsilonis S, Keller J (2020) Crosstalk of brain and bone-clinical observations and their molecular bases. Int J Mol Sci 21(14):4946. https://doi. org/10.3390/ijms 21144946

Owens AP (2020) The role of heart rate variability in the future of remote digital biomarkers. Front Neurosci 13(14):582145. https://doi.org/10.3389/fnins.2020.582145.eCollection2020

Oxford AE, Jorcyk CL, Oxford JT (2016) Neuropathies of StüveWiedemann syndrome due to mutations in leukemia inhibitory factor receptor (LIFR) gene. J Neurol Neuromedicine 1(7):3744. https://doi.org/10.29245/2572.942x/2016/7.1068

Peek SL, Mah KM, Weiner JA (2017) Regulation of neural circuit formation by protocadherins. Cell Mol Life Sci 74(22):4133-4157. https://doi.org/10.1007/s00018-017-2572-3 (Epub 19 Jun 2017)

Porte D Jr, Williams RH (1966) Inhibition of insulin release by norepinephrine in man. Science 152(3726):1248-1250. https://doi. org/10.1126/science.152.3726.1248
Pudela C, Balyasny S, Applebaum MA (2020) Nervous system: embryonal tumors: neuroblastoma. Atlas Genet Cytogenet Oncol Haematol 24(7):284-290. https://doi.org/10.4267/2042/70771

Purves D, Wigston DJ (1983) Neural units in the superior cervical ganglion of the guinea-pig. J Physiol 334:169-78. https://doi. org/10.1113/jphysiol.1983.sp014487

Quarti-Trevano F, Seravalle G, Dell'Oro R, Mancia G, Grassi G (2021) Autonomic cardiovascular alterations in chronic kidney disease: effects of dialysis, kidney transplantation, and renal denervation. Curr Hypertens Rep 23(2):10. https://doi.org/10.1007/ s11906-021-01129-6

Quirke V (2006) Putting theory into practice: James Black, receptor theory and the development of the beta-blockers at ICI, 1958-1978. Med Hist 50(1):69-92. https://doi.org/10.1017/s0025727300009455

Raabe EH, Laudenslager M, Winter C, Wasserman N, Cole K, LaQuaglia M, Maris DJ, Mosse YP, Maris JM (2008) Prevalence and functional consequence of PHOX2B mutations in neuroblastoma. Oncogene 27(4):469-476. https://doi.org/10.1038/sj.onc.1210659 (Epub 16 Jul 2007)

Rankin LC, Artis D (2018) Beyond host defense: emerging functions of the immune system in regulating complex tissue physiology. Cell 173(3):554-567. https://doi.org/10.1016/j.cell.2018.03.013

Reiff T, Tsarovina K, Majdazari A, Schmidt M, del Pino I, Rohrer H (2010) Neuroblastoma phox $2 b$ variants stimulate proliferation and dedifferentiation of immature sympathetic neurons. J Neurosci 30(3):905-915. https://doi.org/10.1523/JNEUROSCI. 5368-09.2010

Reissmann E, Ernsberger U, Francis-West PH, Rueger D, Brickell PM, Rohrer H (1996) Involvement of bone morphogenetic protein-4 and bone morphogenetic protein-7 in the differentiation of the adrenergic phenotype in developing sympathetic neurons. Development 122(7):2079-2088

Richard D, Monge-Roffarello B, Chechi K, Labbé SM, Turcotte EE (2012) Control and physiological determinants of sympathetically mediated brown adipose tissue thermogenesis. Front Endocrinol (Lausanne) 3:36. https://doi.org/10.3389/fendo.2012. 00036. eCollection 2012

Rodriguez-Iturbe B, Pons H, Johnson RJ (2017) Role of the immune system in hypertension. Physiol Rev 97(3):1127-1164. https:// doi.org/10.1152/physrev.00031.2016

Rohrer H (2011) Transcriptional control of differentiation and neurogenesis in autonomic ganglia. Eur J Neurosci 34(10):1563-1573. https://doi.org/10.1111/j.1460-9568.2011.07860.x

Rohrer H, Thoenen H (1987) Relationship between differentiation and terminal mitosis: chick sensory and ciliary neurons differentiate after terminal mitosis of precursor cells, whereas sympathetic neurons continue to divide after differentiation. J Neurosci 7(11):3739-3748. https://doi.org/10.1523/JNEUROSCI.07-11-03739.1987

Rosenblueth A, Simeone FA (1934) The interrelations of vagal and accelerator effects on the cardiac rate. Am J Physiol 110(1):42-55

Rothman TP, Gershon MD, Holtzer H (1978) The relationship of cell division to the acquisition of adrenergic characteristics by developing sympathetic ganglion cell precursors. Dev Biol 65(2):322341. https://doi.org/10.1016/0012-1606(78)90030-1

Rua R, McGavern DB (2018) Advances in meningeal immunity. Trends Mol Med 24(6):542-559. https://doi.org/10.1016/j.molmed. 2018.04.003 (Epub 3 May 2018)

Samaan A (1935) The antagonistic cardiac nerves and heart rate. J Physiol 83(3):332-340

Sasaki H, Kawamura N, Dyck PJ, Dyck PJB, Kihara M, Low PA (2020) Spectrum of diabetic neuropathies. Diabetol Int 11(2):8796. https://doi.org/10.1007/s13340-019-00424-7

Sata Y, Head GA, Denton K, May CN, Schlaich MP (2018) Role of the sympathetic nervous system and its modulation in renal 
hypertension. Front Med (Lausanne) 5:82. https://doi.org/10. 3389/fmed.2018.00082. eCollection 2018

Savarese G, Lund LH (2017) Global public health burden of heart failure. Card Fail Rev 3(1):7-11. https://doi.org/10.15420/cfr.2016:25:2

Schlaich MP, Hering D, Sobotka PA, Krum H, Esler MD (2012) Renal denervation in human hypertension: mechanisms, current findings, and future prospects. Curr Hypertens Rep 14(3):247-253. https://doi.org/10.1007/s11906-012-0264-9

Schneider C, Wicht H, Enderich J, Wegner M, Rohrer H (1999) Bone morphogenetic proteins are required in vivo for the generation of sympathetic neurons. Neuron 24(4):861-870. https://doi.org/ 10.1016/s0896-6273(00)81033-8

Scholz M, Haase R, Schriefer D, Voigt I, Ziemssen T (2021) Electronic health interventions in the case of multiple sclerosis: from theory to practice. Brain Sci 11(2):180. https://doi.org/10.3390/brainsci11020180

Schotzinger R, Yin X, Landis S (1994) Target determination of neurotransmitter phenotype in sympathetic neurons. J Neurobiol 25(6):620-639. https://doi.org/10.1002/neu.480250605

Sharma N, Deppmann CD, Harrington AW, St Hillaire C, Chen ZY, Lee FS, Ginty DD (2010) Long-distance control of synapse assembly by target-derived NGF. Neuron 67(3):422-434. https:// doi.org/10.1016/j.neuron.2010.07.018

Shah NM, Groves AK, Anderson DJ (1996) Alternative neural crest cell fates are instructively promoted by TGFbeta superfamily members. Cell 85(3):331-343. https://doi.org/10.1016/s00928674(00)81112-5

Shi Z, Wong J, Brooks VL (2020) Obesity: sex and sympathetics. Biol Sex Differ 11(1):10. https://doi.org/10.1186/s13293-020-00286-8

Shimazu T (1996) Innervation of the liver and glucoregulation: roles of the hypothalamus and autonomic nerves. Nutrition 12(1):65-66. https://doi.org/10.1016/0899-9007(96)00060-3

Silanikove N (1994) The struggle to maintain hydration and osmoregulation in animals experiencing severe dehydration and rapid rehydration: the story of ruminants. Exp Physiol 79(3):281-300. https://doi.org/10.1113/expphysiol.1994.sp003764

Singh KK, Park KJ, Hong EJ, Kramer BM, Greenberg ME, Kaplan DR, Miller FD (2008) Developmental axon pruning mediated by BDNF-p75NTR-dependent axon degeneration. Nat Neurosci 11(6):649-658. https://doi.org/10.1038/nn.2114 (Epub 1 Apr 2008 PMID: 18382462)

Sobotka PA, Mahfoud F, Schlaich MP, Hoppe UC, Böhm M, Krum H (2011) Sympatho-renal axis in chronic disease. Clin Res Cardiol 100(12):1049-1057. https://doi.org/10.1007/s00392-011-0335-y (Epub 19 Jun 2011)

Stanke M, Duong CV, Pape M, Geissen M, Burbach G, Deller T, Gascan H, Otto C, Parlato R, Schütz G, Rohrer H (2006) Target-dependent specification of the neurotransmitter phenotype: cholinergic differentiation of sympathetic neurons is mediated in vivo by gp 130 signaling. Development 133(1):141-150. https://doi.org/10.1242/ dev.02189 (Epub 30 Nov 2005)

Sternberg Z (2018) Cardiovascular Autonomic Dysfunction: Link Between Multiple Sclerosis Osteoporosis and Neurodegeneration. Neuromolecular Med 20(1):37-53. https://doi.org/10.1007/ s12017-018-8481-2 (Epub 10 Feb 2018)

Stevens-Felten SY, Bellinger DL (1997) Noradrenergic and peptidergic innervation of lymphoid organs. Chem. Immunol 69:99-131. [PubMed: 935396]

Taborsky GJ Jr, Ahren B, Mundinger TO, Mei Q, Havel PJ (2002) Autonomic mechanism and defects in the glucagon response to insulin-induced hypoglycaemia. Diabetes Nutr Metab 15(5):318322; discussion 322-323

Takeda S, Elefteriou F, Levasseur R, Liu X, Zhao L, Parker KL, Armstrong D, Ducy P, Karsenty G (2002) Leptin regulates bone formation via the sympathetic nervous system. Cell 111(3):305-317. https://doi. org/10.1016/s0092-8674(02)01049-8
Tansey EA, Johnson CD (2015) Recent advances in thermoregulation. Adv Physiol Educ 39(3):139-148. https://doi.org/10.1152/advan. 00126.2014

Task Force of the European Society of Cardiology and the North American Society for Pacing and Electrophysiology (1996) Heart rate variability: standards of measurement, physiological interpretation and clinical use. Circulation 93(5):1043-1065

Tomlinson RE, Christiansen BA, Giannone AA, Genetos DC (2020) The role of nerves in skeletal development, adaptation, and aging. Front Endocrinol (Lausanne) 11:646. https://doi.org/10. 3389/fendo.2020.00646. eCollection 2020

Tomolonis JA, Agarwal S, Shohet JM (2018) Neuroblastoma pathogenesis: deregulation of embryonic neural crest development. Cell Tissue Res 372(2):245-262. https://doi.org/10.1007/s00441-0172747-0 (Epub 8 Dec 2017)

van Groningen T, Koster J, Valentijn LJ, Zwijnenburg DA, Akogul N, Hasselt NE, Broekmans M, Haneveld F, Nowakowska NE, Bras J, van Noesel CJM, Jongejan A, van Kampen AH, Koster L, Baas F, van Dijk-Kerkhoven L, Huizer-Smit M, Lecca MC, Chan A, Lakeman A, Molenaar P, Volckmann R, Westerhout EM, Hamdi M, van Sluis PG, Ebus ME, Molenaar JJ, Tytgat GA, Westerman BA, van Nes J, Versteeg R (2017) Neuroblastoma is composed of two super-enhancer-associated differentiation states. Nat Genet 49(8):1261-1266. https://doi.org/10.1038/ng.3899 (Epub 26 Jun 2017)

van Limpt V, Chan A, Schramm A, Eggert A, Versteeg R (2005) Phox2B mutations and the Delta-Notch pathway in neuroblastoma. Cancer Lett 228(1-2):59-63. https://doi.org/10.1016/j. canlet.2005.02.050

von Bezold A (1863) Untersuchungen über die Innervation des Herzens. Engelmann, Leipzig

Walker MJ (2011) The major impacts of James Black's drug discoveries on medicine and pharmacology. Trends Pharmacol Sci 32(4):183-188. https://doi.org/10.1016/j.tips.2011.02.001 (Epub 15 Mar 2011)

Walston JD (2015) Connecting age-related biological decline to frailty and late-life vulnerability. Nestle Nutr Inst Workshop Ser 83:110. https://doi.org/10.1159/000382052 (Epub 20 Oct 2015)

Wang L, Tan TK, Durbin AD, Zimmerman MW, Abraham BJ, Tan SH, Ngoc PCT, Weichert-Leahey N, Akahane K, Lawton LN, Rokita JL, Maris JM, Young RA, Look AT, Sanda T (2019) 2019 ASCL1 is a MYCN- and LMO1-dependent member of the adrenergic neuroblastoma core regulatory circuitry. Nat Commun 10(1):5622. https://doi.org/10.1038/s41467-019-13515-5

Wenner MM, Stachenfeld NS (2012) Blood pressure and water regulation: understanding sex hormone effects within and between men and women. J Physiol 590(23):5949-5961. https://doi.org/ 10.1113/jphysiol.2012.236752 (Epub 1 Oct 2012)

Winslow JB (1732) Exposition anatomique de la structure du corps humain. Published by G. Desprez and J. Desessartz (Paris)

Winter EM, Ireland A, Butterfield NC, Haffner-Luntzer M, Horcajada MN, Veldhuis-Vlug AG, Oei L, Colaianni G, Bonnet N (2020) Pregnancy and lactation, a challenge for the skeleton. Endocr Connect 9(6):R143-R157. https://doi.org/10.1530/EC-20-0055

Wrona D (2006) Neural-immune interactions: an integrative view of the bidirectional relationship between the brain and immune systems. J Neuroimmunol 172(1-2):38-58. https://doi.org/10. 1016/j.jneuroim.2005.10.017 (Epub 10 Jan 2006)

Zafar A, Wang W, Liu G, Wang X, Xian W, McKeon F, Foster J, Zhou J, Zhang R (2021) Molecular targeting therapies for neuroblastoma: progress and challenges. Med Res Rev 41(2):961-1021. https://doi.org/10.1002/med.21750 (Epub 6 Nov 2020)

Zhang DY, Anderson AS (2014) The sympathetic nervous system and heart failure. Cardiol Clin 32(1):33-45, vii. https://doi.org/10. 1016/j.cc1.2013.09.010 
Zhang RM, McNerney KP, Riek AE, Bernal-Mizrachi C (2021) Immunity and hypertension. Acta Physiol (Oxf) 231(1):e13487. https:// doi.org/10.1111/apha.13487. Epub 25 Jun 2020
Publisher's Note Springer Nature remains neutral with regard to jurisdictional claims in published maps and institutional affiliations. 